\title{
Ideology and Strategic Party Disloyalty in the US House of Representatives*
}

\author{
Justin H. Kirkland ${ }^{\dagger}$ \\ Jonathan B. Slapin ${ }^{\ddagger}$ \\ jhkirkland@uh.edu \\ jslapin@essex.ac.uk
}

\begin{abstract}
We offer a theory of strategic party disloyalty to explain roll call voting in the US House. Our theory suggests that ideologically extreme legislators become markedly less loyal to their party when it controls the majority. They stake out positions that align with the views of their extreme constituents when policy is likely to move in their direction. In contrast, ideological moderates become noticeably more loyal when they transition to the majority. Examining 35 years of ideal point estimates and measures of party unity on roll calls, we find clear evidence that member strategy, ideology, and legislative agenda setting interact to structure the frequency of defections. Further, we find evidence that defection and ideology interact to influence subsequent electoral outcomes.
\end{abstract}

Keywords: Legislative Politics; Party Loyalty; Ideological Extremity

Word Count: 11,286

\footnotetext{
${ }^{*}$ We will make the full replication code and data available upon publication of the article.

${ }^{\dagger}$ Department of Political Science, University of Houston

${ }^{\ddagger}$ Department of Government, University of Essex
} 
During his time in Congress, Ohio Democrat Dennis Kucinich's (D-OH 10th) voting record placed him reliably among the most liberal members of Congress. Likewise, Texas Republican Ron Paul's (R-TX 14th) voting patterns were consistently among the most conservative. Both men attracted media attention for possessing an independent streak and for their failed presidential campaigns. While Kucinich and Paul may have held steadfastly true to their ideological roots, their partisanship on roll call votes varied significantly across time and followed a remarkably similar pattern. When their parties were in the minority they were highly loyal partisans; but once their parties secured a majority, they defected more frequently. Kucinich voted with the majority of Democrats on $96 \%$ to $97 \%$ of votes during the 108th, 109th and 112th Congresses while in the minority. With the Democrats in the majority during the 110th and 111th, Kucinich's loyalty dropped to $93 \%$ and $91 \%$ respectively. When Republicans were the majority party prior to the 110th Congress, Paul voted with his party on between $70 \%$ and $78 \%$ of votes. When in the minority during 110 th and 111th, his loyalty increased to $86 \%$ and $89 \%$, respectively. With the Republicans once again holding the majority in the 112 th his loyalty fell back to just over $80 \%$. Moderates do the opposite. New Jersey Republican Chris Smith (R-NJ 4th), who has one of the House's most moderate voting records, was least loyal to his party when in the minority, voting with the majority of Republicans on $64 \%$ and $72 \%$ of votes in the 110 th and 111 th respectively. He was most loyal when the Republicans held the majority in the 109th and 112th (76\% and 81\%). Likewise, moderate New Jersey Democrat Steve Rothman (D-NJ 9th) was most loyal when in the majority during the 110th and 111th, and less loyal in the minority during the 109th and 112th.

These patterns are puzzling when considering the dominant models of legislative behavior in Congress. Spatial voting models would suggest that party defectors should come from the ideological middle - moderates may occasionally cross the aisle to vote with the other party (Downs, 1957; Poole, 2005). No current model suggests defection patterns should change depending on the partisan control of the House. The predictions of the spatial model are so strong, and the model classifies votes so well, that until recently relatively few scholars of Congress have even bothered to examine and explain individual members' decisions to defect from their party (but see Carson et al., 2010; Lindstädt and Vander Wielen, 2014; Minozzi and Volden, 2013). Instead, scholars focus on 
explanations for aggregate voting patterns, such as party unity (e.g. Lebo, McGlynn and Koger, 2007). In the aggregate, voting patterns are remarkably stable across time (Poole and Rosenthal, 2007), the majority party tends to be better disciplined and rarely gets rolled (Cox and McCubbins, 2005), and, as the spatial model suggests, moderates are more likely than extremists to defect to vote with the other party (Kirkland, 2014).

However, when we turn from aggregate patterns to individual-level behavior, parties, legislative agenda-setting, and ideology interact to produce patterns that do not conform to the spatial voting model. Namely, House members on the ideological fringe become more loyal when their party is in the minority and less loyal when their party is in the majority, while moderates become more loyal when in the majority and less loyal when in the minority. These patterns suggest that the interaction between partisan control and individual ideology is different than the patterns suggested by the standard models of parties in Congress (e.g. Aldrich and Rohde, 2001; Cox and McCubbins, 1993, 2005; Krehbiel, 1998). They demonstrate that members' individual strategies, ideology, and the agenda setting institutions in legislatures interact to structure decisions about whether to support or oppose to one's party. Moreover, the voting patterns we uncover are relatively recent ones. One could only possibly observe these patterns, at least for the modern Congress, beginning in 1995 when partisan control changed hands for the first time since 1955. These shifts in partisan majorities allow us to examine how individual member behavior changes when parties move from the minority to the majority.

Our findings lend credence to ideas found in the popular press, and recently propounded by Thomas Mann and Norman Ornstein, that American parties are behaving increasingly like those in parliamentary systems, often to detrimental effect (Mann and Ornstein, 2012). The defection patterns we observe are more familiar to students of Westminster parliamentary democracy, where strong party loyalty and government versus opposition voting are the norm (Dewan and Spirling, 2011); but defections are more likely to come from ideological extremists than moderates (Benedetto and Hix, 2007; Gaines and Garrett, 1993; Kam, 2009). Moreover, in these systems extremists defect for non-spatial, ideological reasons (Spirling and McLean, 2006) to connect with constituents and to build a "brand" separate from that of their party (Proksch and Slapin, 2012, 2015). As Congress 
becomes increasingly polarized (Carson et al., 2007; Theriault, 2008), we would expect a greater share of defections to come from majority party extremists, as in Westminster systems. While differences in party and MP behavior between the US Congress and Westminster parliamentary systems are clearly substantial, we provide further evidence that these differences are more a matter of degree than of kind.

The paper offers a new theory of strategic party loyalty to explain individual-level voting behavior in Congress, in particular during the last twenty years of shifting partisan control. We argue that partisan and electoral pressures affect members differently depending upon their ideology and institutional position within Congress. Namely, moderates are more likely to be disloyal when in the minority, while extremists are strategically disloyal when in the majority. To win reelection, moderates are more likely to rely on bringing goods, which the majority party can provide, back to their district, perhaps in the form of legislative success or support for local projects. Therefore, they are are more susceptible to pressure from their own party when it is in the majority, and they are less susceptible when in the minority. Extremists, in contrast, are more likely to gain electoral support by making a name for themselves through ideological grandstanding. While they are more loyal to their party than moderates on average, they care more about their personal ideological "brand" and they are less beholden to the party message. Defecting from the party helps them generate name recognition and it is particularly effective when their party is in the majority. Extremists can also use defection as leverage to motivate their party leaders to consider more extreme policy proposals favored by their electorate. When in the minority, the party leadership has an incentive to move towards the extreme to offer policy alternatives to the majority. Moreover, because legislative proposals that come to the floor are more likely to originate with the majority, they are likely opposed by a majority of the opposition including the extremists. Thus, extremists look more loyal in the minority.

In what follows, we first review the predictions of the spatial model with respect to partisan defections and review the existing literature on parties in Congress. We then develop our theory of strategic party loyalty and examine its implications for individual-level defections. We demonstrate empirically that ideology and majority status interact to explain members' defections from their 
party. Moreover, we find that defections affect electoral outcomes differently for moderates and extremists in a manner consistent with our theory. We conclude by drawing implications for parties that, to date, have been overlooked in the literature on parties in the US Congress.

\section{Proximity Models of Legislative Voting}

A wide array of theoretical and empirical models used to study legislative choices assume a Downsian, or spatial, model of legislative decision making (Downs, 1957). That is, when legislators decide how to vote on a bill they compare the spatial location of policies implied by the bill to both their own preferences for policy outcomes and to the status quo. When a legislator's own preferences are more proximate to the status quo the legislator opposes the new policy, and when a legislator's own preferences are more proximate to the new policy the legislator supports that policy. The proximity model of legislative decisions has been extremely successful in describing the roll call voting behavior of members of Congress (MCs) and forms the basis for most tools used to estimate legislative ideal points (e.g. Poole and Rosenthal, 1985; Clinton, Jackman and Rivers, 2004; Carroll et al., 2013) as well as playing a key role in many theories of legislative organization (Cox and McCubbins, 1993, 2005; Krehbiel, 1998; Shepsle and Weingast, 1987).

Nevertheless, the proximity model has very little to say about parties and their involvement in legislative decision-making (Krehbiel, 1998). Indeed, it assumes that individual legislators cast roll call votes under no (or very weak) party constraints. Despite, or perhaps because of, the ubiquity of the proximity model, scholars have dedicated much effort to finding evidence for the role of parties in Congress (e.g. Aldrich, 1995; Binder, 1996, 1997; Cox and McCubbins, 1993, 2005; Rohde, 1991), and to assessing the conditions under which our empirical models can distinguish between situations of weak party and strong party governance (Krehbiel, 2000; Krehbiel, Meirowitz and Romer, 2005). However, as Krehbiel (2000) notes, most measures of party influence on roll call votes examine aggregate party unity using Rice scores (Rice, 1925) (e.g. Binder, 1996) or support

for party leadership votes (e.g. Cox and McCubbins, 1993). Krehbiel (1993, 2000) demonstrates that these aggregate measures are particularly poor at distinguishing between situations of weak 


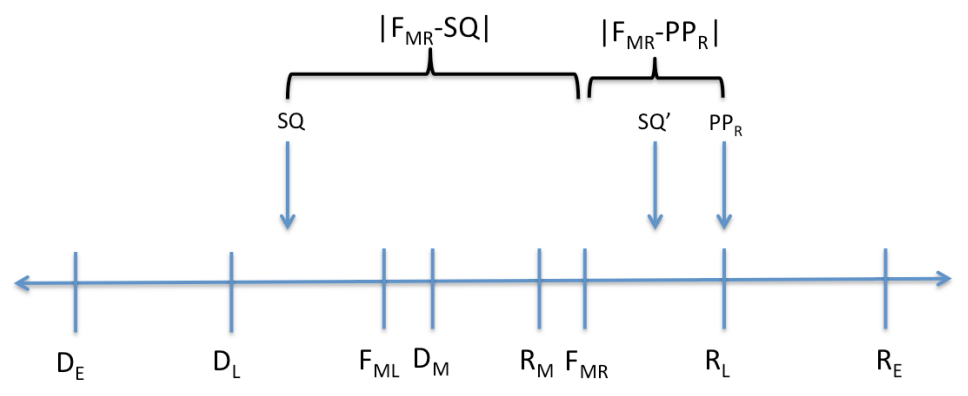

More Liberal

More Conservative

Figure 1: The Spatial Voting Model in the Presence of Legislative Agenda-Setting

and strong party influence. None of these empirical studies in search of party influence look at individual legislators' decisions to defect from their party on votes.

Despite not saying much about parties, the spatial model does have important implications for party loyalty, some of which have been recently called into question (Minozzi and Volden, 2013). In particular, if political parties can structure the legislative agenda by controlling key veto points in the chamber as suggested by Cox and McCubbins (2005), and individual legislators use spatial logic to make choices about which bills to support, then under a reasonable set of assumptions about the location of the status quo ideological extremists should be the most likely to support their party's proposals. ${ }^{1}$ The legislators least likely to support their party's proposals should come from the ideologically moderate wings of a party.

Figure 1 makes clear the assumptions regarding individual legislators' calculus for which the above statements are true. The figure presents an arbitrary liberal-conservative ideological space. $D_{e}$ and $R_{e}$ represent the ideal points of Democratic and Republican extremists respectively; $D_{m}$ and $R_{m}$ the ideal points of Democratic and Republican moderates; and $D_{L}$ and $R_{L}$ the position of the respective party leaderships (assumed to be near the party medians). $F_{M D}$ and $F_{M R}$ represent the positions of hypothetical floor medians under Democratic and Republican majorities, respec-

\footnotetext{
${ }^{1}$ Namely, this relationship holds for the set of Republican proposals that are less liberal than the current status quo and the set of Democratic proposals less conservative than the current status quo.
} 
tively. Thus, we assume that the floor median moves left to right with a shift from Democratic to Republican leadership, and vice versa. $S Q$ represents an arbitrary status quo position located to the left of the Republican party leadership and $P P_{R}$ is the position of a Republican policy proposal with the House under Republican control. Whenever $\left|F_{M R}-S Q\right|>\left|F_{M R}-P P_{R}\right|$, the floor median supports the proposal over the status quo and it passes.

Let us assume that Republicans are the majority party, control the agenda, and wish their bills to pass. Thus, following Cox and McCubbins (2005), they only bring to the floor those proposals that the floor median $F_{M R}$ prefers to the status quo $S Q$. Given agenda-setting powers, the Republican party leadership select a $P P_{R}$ as close to $R_{L}$ as possible while still being supported by $F_{M R}$ over $S Q$. Under these conditions the only Republican legislators more proximate to $S Q$ than to PP would come from the moderate wings of the party. Moderates holding ideal points to the left of $F_{M R}$ would rebel because the leadership only has to satisfy the more conservative floor median. Extremist Republicans would only have a spatial incentive to defect if the $S Q$ were located to the right of the Republican leadership, causing the Republican leadership to push for change in a moderate (or liberal) direction. In this instance, we would expect all members of Congress, liberal and conservative, to support the Republican leadership's proposal, except those few conservative extremists closer to the $S Q .^{2}$ Thus, for members of the majority party, we would never expect extremists to rebel on votes that divide the parties, but we do expect moderates (those more liberal than $F_{M R}$ ) to rebel on votes when their own leadership moves policy too far right relative to the $S Q$.

Now consider how spatial incentives change for moderates when their party becomes the minority and agenda control shifts. The floor median shifts left, from $F_{M R}$ to $F_{M L}$ and the majority Democrats seek to move policy to left. Namely, they seek to alter policies with right-of-center

${ }^{2}$ Empirically, we only examine party unity votes - those on which a majority of Democrats vote against a majority of Republicans. According to the spatial model, the $S Q$ would need to lie between the party medians for the cutline dividing "yea's" from "nay's" to fall between the two parties. Thus, these scenarios of extreme $S Q$ positions and overwhelming bipartisan support are not considered in our data or most other studies examining party unity scores. 
status quo positions such as $S Q^{\prime}$. In the minority, only moderate Republicans ever have a spatial incentive to rebel from their party majority — any Democratic proposal that Republican extremists prefer over $S Q^{\prime}$ must also be preferred by Republican moderates. However, these Republican moderates should not rebel very often. Because the Democratic proposal, $P P_{D}$, only has to leave the center-left floor median, $F_{M L}$, better off compared with $S Q^{\prime}$, only Republican moderates sufficiently liberal to prefer such a $P P_{D}$ would vote with the Democrats and against their party majority. Moreover, for any $S Q^{\prime}$ and $D_{L}$ such that the Democratic leadership can propose $D_{L}$ and receive $R_{M}$ 's support (rebelling against the majority of Republicans), $R_{M}$ would also rebel if Republicans were to come to power and propose to shift the same $S Q^{\prime}$ in a more conservative direction. Thus, such a moderate is either equally likely or more likely to rebel when in the majority. Additionally, any Republican moderate with an ideal point more liberal than the center-right floor median under Republican control, $F_{M R}$ and who remains loyal to the party when in the minority, would rebel on the same issue given the same $S Q^{\prime}$ when Republicans control the majority and attempt to move policy rightward.

Spatial logic, coupled with legislative agenda-setting implies that moderates rebel more frequently when their party is in majority whenever: 1) very few moderate Republicans prefer Democratic Party proposals designed to satisfy the center-left floor median under Democratic control, 2) very few moderate Democrats prefer Republican Party proposals designed to satisfy the centerright floor median under Republican control, and 3) moderates tend to lie between the current floor median and the hypothetical floor median should control of the House change hands. These conditions are particularly likely to hold in the presence of polarized parties, where the two hypothetical floor medians are likely further apart and we would see moderates on the opposite side of the floor median from their party leadership only rarely. From this model we derive the following propositions:

- Spatial Proposition 1: Moderates defect from their party majority more often than extremists.

- Spatial Proposition 2: Moderates defect from their party majority more often when they belong to the majority party than the minority party. 
- Spatial Proposition 3: Extremists are highly loyal partisans regardless of their party's majority status.

The individual level defection patterns that we described in the introduction — patterns that we demonstrate below are quite robust and in no way limited to the four individuals described there - are the opposite of those suggested by Propositions $2 \& 3$. We demonstrate that in aggregate moderates are more disloyal than extremists, as suggested by Proposition 1, but Propositions 2 \& 3 find no support in the data. Instead, we demonstrate that legislative agenda setting institutions controlled by the majority party of the House interact with ideology and member strategy to produce these patterns of defection. These findings suggest that spatial logic alone cannot explain defections on roll call votes.

Interestingly, the existing literature on party loyalty and partisan voting, while providing evidence of party influence over members, also cannot explain the patterns we observe, nor does it consider the effects of majority status on defection from one's party. ${ }^{3}$ For example, Carson et al. (2010) examine the effects of party unity on electoral outcomes. They find that ideological extremists are more likely to be loyal partisans, controlling for electoral safety, and that higher party unity can be electorally costly, implying that parties are careful in selecting whom to pressure. However, they do not examine how these patterns may fluctuate with partisan control. Likewise, Lindstädt and Vander Wielen $(2011,2014)$ find strong support for fluctuation in party loyalty over time as a function of electoral and partisan pressures, but do not examine whether party control of the chamber affect these pressures. Lastly, Minozzi and Volden (2013) find that that party pressure affects extremists and moderates differently, and while they do control for majority status, they do not examine the interaction of majority status and ideology — specifically, they do not examine how

\footnotetext{
${ }^{3}$ Lawrence, Maltzman and Smith (2006) do examine an empirical model that interacts ideology with partisanship, but their primary interest is in predicting the frequency with which a legislator votes on the winning side of a bill, not with a legislator's level of party loyalty. Additionally, nothing in their models would suggest that ideological extremists become less loyal when their party obtains majority status. Further, their argument for the conditional effects of ideology on voting centers on agenda control, rather the electoral motivation hypotheses that we develop and test.
} 
individual member behavior changes when parties switch majority-minority status. ${ }^{4}$ Additionally, more macro-oriented accounts of party loyalty like Lebo, McGlynn and Koger (2007) and Patty (2008) provide theoretical explanations for changes in aggregate party loyalty over time, but are less able to explain individual variations in party loyalty. ${ }^{5}$ Similarly, research on conditional party government (CPG) has demonstrated that a number of institutions might be used increase rankand-file loyalty, but the CPG framework provides no reason to believe that these institutions might increase moderates' loyalty while decreasing extremists' loyalty (Rohde, 1991; Crook and Hibbing, 1985; Shepsle, 1978). We build on this literature by testing a theory of party support that suggests party pressure affects individual members differently over time depending upon an interaction of ideology and control of the agenda (majority party status) of the House, reflecting the fact that members at different points in the ideological distribution of parties are likely to utilize different legislative strategies.

\section{A Theory of Strategic Party Disloyalty}

Two basic assumptions lie at the heart of our theoretical argument. The first assumption is that the majority party can pass legislation that moves policy in its favored direction and away from the position of the minority party. Thus, the majority party exercises a significant degree of agenda control (Cox and McCubbins, 2005) and has the resources to obtain the votes it needs

${ }^{4}$ Minozzi and Volden (2013) do include 5th order polynomials of their key independent variables allowing them to detect nonlinearities in the effects of ideal points on party loyalty. But detecting nonlinearities in the effect of ideology on party loyalty, and interacting ideology with party status to detect conditional effects of ideology on party loyalty are empirically different quantities.

${ }^{5}$ In particular, Lebo, McGlynn and Koger (2007) suggest that the average level of loyalty within a party is a strategic function of the loyalty in the opposing party. Patty (2008), alternatively suggests that the average level of loyalty in parties is a function of the size of opposing parties. Neither of these accounts provide predictions about why individuals change their party loyalty over the course of their careers as a function of their place in the ideological distribution of their party. 
to pass policy. The second assumption is that ideological moderates and extremists connect with constituents in different ways (Fenno, 1978). ${ }^{6}$ Namely, as members hold more ideologically extreme views, they become more likely to align ideologically with their party's core voters, and emphasize ideological positions. In contrast, members holding more moderate views tend to focus more on policy gains and less on ideological position-taking. Extremists commit to an "ideological brand" to send clear, consistent messages of extremity to voters who agree with them, while moderates focus on policy outcomes and securing distributive benefits for their constituents (Grimmer, 2013a,b). ${ }^{7}$ Taken together, these two assumptions imply very different patterns of party loyalty for extreme and moderate members that depend on their party's majority status.

We begin by examining incentives for extremists. As members hold more extreme views, they invest more in their ideological brand, and any action that dilutes their message could prove costly, even if the action assists in moving policy in their preferred direction. Said differently, ideological extremists are likely to vote against legislation that insufficiently moves the status quo in their

${ }^{6}$ For ease of exposition, we discuss two types of members - moderates and extremists. Of course, this dichotomy is a simplification as members exist along an ideological continuum. The pressures we discuss are most pronounced for the most extreme and most moderate members. But they, too, exist along a continuum. In the empirical analysis we examine all members across the entire ideological space.

${ }^{7}$ Most voters do not possess a sophisticated understanding of ideological distance and congressional voting. They are unlikely to recognize or pay attention to nuanced movements in policy positions, but they can recognize a member's commitment to an ideological stance and they observe the benefits their district receives through their representative, particularly when interest groups and media communicate these actions to voters. Indeed, extant evidence suggests both that voters prefer uncompromising representatives and that excessive partisan loyalty can be electorally damaging (Carson et al., 2010; Harbridge, Malhotra and Harrison, 2014), especially in extreme constituencies (Harbridge and Malhotra, 2011). Thus, undermining ideological purity to move policy is a sub-optimal electoral strategy for representatives in extreme districts. 
preferred direction for fear that they may be labeled as compromisers. ${ }^{8}$ They may also take advantage of the opportunity to defect in order to force future party proposals in a more ideologically extreme direction. For these representatives, the position of the status quo is less important than the position of the eventual policy outcome, and they are prone to ideological grandstanding — that is, opposing legislation that moves policy in their preferred direction by an insufficient amount. ${ }^{9}$ Tea Party Republicans' opposition to the 2011 debt ceiling deal provides an example of this kind of behavior. Speaker Boehner's (R-OH) plan to raise the U.S. debt ceiling came with more than $\$ 917$ billion in cuts to government spending while only increasing the debt ceiling by $\$ 900$ billion. Even extreme Republican members should have preferred this plan to the status quo, but many ideologically extreme members like Michelle Bachman (R-MN), Todd Akin (R-MO), and Ron Paul (R-TX) opposed the debt plan as a way to demonstrate their commitment to conservative principles. In contrast, more moderate members have less to lose by taking an action that could be construed as a deviation from any particular ideology. Rather, they pursue a strategy that allows them to connect with their constituents by highlighting what they have accomplished for their district. They may focus on porkbarrel politics or their ability to achieve legislative success through bipartisanship.

The effects that these strategies have on party loyalty depend on a member's party majority status precisely because majority parties are better able to move policy in their direction. As an extremist becomes more certain that policy will change in her preferred direction, she cares less about the position of the status quo - it will change regardless of what she does. Instead, maximizing benefits (either electorally, within one's party, or both) from position-taking takes precedence. In other words, as the status quo becomes less important, the extremist becomes increasingly likely to defect from her party majority to avoid the appearance of compromise on

${ }^{8}$ The pejorative term RINO - Republican in Name Only - provides an illustration of this logic. Some Republican members fear being construed as insufficiently conservative or betraying conservative principles in their pursuit of policy victories. Extremists are more likely to be electorally damaged by such a label, thus their concern for position-taking should be largest.

${ }^{9}$ It is important to point out that our theory emphasizes extremists' investment in their ideological brand, not their partisan brand. 
a less than perfect proposal. She gains electorally by maintaining her ideological purity and by signaling her willingness to stand up for her ideology in the face of party pressure. When in the minority, this same ideologue appears highly loyal to her party by behaving in the same manner. She opposes the policy changes suggested by the majority party, but so does the majority of her own party because policy is moving away from them. In the minority, standing up for position-taking and purely spatial reasons are observationally equivalent, and both make the extremists appear loyal to their party majority.

Indeed, an ideal strategy for this extremist when in the majority party is to both support her party's efforts to change the status quo, thus avoiding party pressures and penalties, while appearing to remain ideological pure to her constituents. This sort of strategic disloyalty would be difficult to accomplish if all votes were final passage votes. However, in the House, most final passage votes on legislation are pro forma with much of the important ideological action happening on procedural votes prior to final passage (Lee, 2008; Theriault, 2008). Thus, a strategically disloyal extremist can help change policy by supporting her party on procedural votes (Crespin, Rohde and Vander Wielen, 2013; Lee, 2008) and appear ideologically pure to her constituents through disloyalty on final passage votes. When she is in the minority party, however, she opposes the majority on both final passage and procedural votes, and thus, appears loyal at all times. This logic implies that as individuals transition from minority party to majority party status, we should expect greater decreases in party loyalty on final passage votes compared with procedural votes among more ideologically extreme members. ${ }^{10}$

More moderate members, in contrast, are more likely to obey traditional policy outcome-based

${ }^{10}$ Interestingly, this argument would also imply that extremists have incentives to invest majority party leaders with significant powers. Such an approach would allow extremists to grandstand against their party without altering the party's ability to achieve its agenda, as much of the party's ability to achieve its agenda would be controlled by a strong leadership. While there would be some risk in supporting strong party leaders in order to ultimately defect against them on occasion, such a strategy might be warranted under conditions of sufficient ideological distance between the parties Rohde (1991, 2013). 
spatial logic as their ideological brand is less important to them, and they are more susceptible to party coercion via threats and rewards. Following Carson et al. (2010), moderates behave as if they are electorally vulnerable. When in the minority, their party does not need their support to pass a legislative agenda. Thus, the minority party places less pressure on their moderates and the moderates appear less loyal. They may cast votes with the majority to take positions that are more in line with the median voter in their constituency, to claim credit for some legislative successes, for ideological/spatial reasons, or to better position themselves to extract benefits from the majority party. ${ }^{11}$ When in the majority, the party is more likely to need the votes of their ideological moderates to achieve the party's legislative goals. Accordingly, the party leadership leans on moderate members more heavily. Again, moderates attempt to extract concessions from their party, which now controls the majority, and to move policy in their preferred direction with little regard for position-taking or ideological purity. Thus, moderates' loyalty increases when they are in the majority because policy moves in a direction they approve of, and they are still trying to extract distributive benefits from the majority.

Much like their extreme counterparts, moderates also have incentives to be strategically disloyal to their party during final passage votes, but more so when they are in the minority party. Minority party moderates can accrue benefits from the majority through disloyalty on procedural votes, but it is harder to signal their ideological independence to voters on these votes, and thus they lack the electoral impact of final passage votes. This implies that the increase in party loyalty among ideological moderates that comes with the transition from minority to majority party status will be greater on final passage votes than on procedural votes.

In sum, minority party members are unable to effectively grandstand because to do so a member must oppose a majority in favor of a bill as well as the majority of his or her party. But most

${ }^{11} \mathrm{~A}$ great deal of legislative scholarship has pointed out that victories in the US House are often much larger than minimum winning coalitions (Groseclose and Snyder, 1996; Wiseman, 2004; Banks, 2000; Carrubba and Volden, 2000). These supermajority victories typically include the minority party's moderates, which help these moderates extract distributive benefits for their districts (Balla et al., 2002; Weingast, 1979, 1994; Engstrom and Vanberg, 2010). 
members of the minority party, regardless of ideological position, wish to vote against the majority, making it difficult for extremists to vote against their party on ideological grounds. When in the minority, more moderate members tend to be less loyal than extremists because they sometimes wish to support majority policies they like or they might be offered goodies by the majority to vote in favor of the bill to secure passage. With a shift to the majority, on average moderates' party loyalty increases as their own party can now offer them policies they support and goodies for reelection. More extreme members of the majority party, however, now have an option to grandstand unavailable to them in the minority. The mere existence of this option means that those extremist members must appear less loyal when they are in the majority.

From our account of strategic party loyalty we derive three hypotheses:

- Hypothesis 1: Extremists are relatively more loyal when their party is in the minority than when in the majority.

- Hypothesis 2: Moderates are relatively more loyal when their party is in the majority than when in the minority.

- Hypothesis 3: These effects are stronger on final passage votes than on procedural votes.

Taken together, support for these hypotheses would provide considerable evidence for our account of strategic party loyalty on roll call voting over the traditional, proximity-based spatial logic. It would imply that at least some roll call voting by House members is part of an effort to appear to oppose their party for the sake of a non-partisan, personal brand. In the next section, we examine roll call data from the 95 th through the 112th Congress to test for these hypotheses. ${ }^{12}$

\footnotetext{
${ }^{12}$ Both our theory and the more traditional models of legislative choice treat each roll call vote as independent. However, if we consider legislating as a dynamic bargaining game and roll calls as potentially interdependent, then it is conceivable that extremists may by disloyal on one vote as an effort to move policy proposals in an extreme direction on future votes. This could also generate increasing extremist defections when in the majority, but would do so for bargaining rather than electorally motivated reasons.
} 


\section{Roll Call Voting, Ideological Extremity, and Majority Party Status}

To test our hypotheses, we make use of two commonly analyzed datasets on roll call voting in the House: first dimension DW-Nominate scores (Poole and Rosenthal, 1985, 2007) and party unity scores. ${ }^{13}$ The latter are calculated as the frequency a legislator votes with the majority of his or her party on roll call votes in which there is some inter-party disagreement.

We begin by examining some simple descriptive statistics to provide initial evidence in support of our hypotheses. Before looking at all members across the entire ideological continuum, as a first, descriptive cut at the data, we identify the $10 \%$ most ideologically extreme and ideologically moderate members of both the Democratic and Republican parties according to DW-Nominate scores for each session of the House of Representatives from the 95th through the 112th Congresses. We do this by examining the absolute value of DW-Nominate scores for each party, identifying the $10 \%$ highest and $10 \%$ lowest DW-Nominate scores. ${ }^{14}$ Table 1 reports the mean levels of party unity on final passage votes for the same sets of moderate and extreme members of each party. The table differentiates party loyalty for extremists and moderates by majority and minority party status, and then reports the difference of means in these loyalty scores using paired t-tests. The $10 \%$ most extreme members of the Democratic Party have a mean level of party loyalty of $88.6 \%$ when in the majority. This scores jumps up to $94.4 \%$ when those same extremists are in the

${ }^{13} \mathrm{DW}-$ Nominate scores are ideal point estimates meant to summarize a legislators' roll call voting behavior via the standard proximity model of legislative choices. The first dimension of a legislator's DW-Nominate score set typically corresponds to what political scientists think of as a liberal-conservative dimension of roll call voting. DW-Nominate scores run from -1 to 1 , with -1 values on the first dimension typically being associated with liberal legislative voting, 1 typically being associated with conservative legislative voting, and 0 representing perfectly moderate roll call voting.

${ }^{14}$ Taking the absolute value folds DW-Nominate scores, such that perfect moderation (a score of 0) becomes the lowest observable score, and a movement away from zero represents increasingly extreme voting behavior. 
Table 1: Difference of Means in Party Loyalty Rates on Final Passage Votes For 10\% Most Moderate and 10\% Most Extreme Partisans (95th-112th Congress)

\begin{tabular}{l|ccc}
\hline \hline Category & Majority Party & Minority Party & Difference in Loyalty \\
\hline Democratic Extremists & 88.625 & 94.447 & $-5.822^{*}$ \\
Democratic Moderates & 56.976 & 49.185 & $7.791^{*}$ \\
Republican Extremists & 87.959 & 90.975 & $-3.016^{*}$ \\
Republican Moderates & 83.745 & 35.248 & $48.498^{*}$ \\
\hline Note: * indicates a p-value $<0.05$ & &
\end{tabular}

minority, implying that the party loyalty of extremists decreases $5.8 \%$ when the Democrats are in the majority. Democratic moderates, alternatively, see their party loyalty increase by roughly $7.8 \%$ when they join the majority. These results are mirrored by the Republican Party members, and each difference in mean loyalty rates is statistically significant at the 0.05 level. ${ }^{15}$

Though the descriptive evidence in Table 1 provides initial support for our expectations, we require more robust statistical evidence before we can be genuinely confident that the party loyalty of extremists and moderates responds to majority party status differently. In particular, our descriptive evidence uses only a subset of members and DW-Nominate scores at time $t$ to examine party unity scores at time $t$. Since these two measures are aggregations of the same set of roll call votes, our descriptive analysis suffers from endogeneity problems. Additionally, our descriptive evidence provides no controls for alternative explanations. There maybe a host of temporal or individual changes driving the patterns in Table 1.

As a next step, Table 2 reports two fractional logit models predicting the probability a legislator votes with his or her party on a roll call vote for the 95th through 112th Congresses for all members. Because party unity scores are proportions (loyal votes over all party line votes), OLS is

${ }^{15}$ It is worth emphasizing that these results are merely descriptive results using an arbitrary cutoff. Our more complete approach to modeling appears in Table 2. In our supplemental appendices, we also vary the $10 \%$ cutoff also using 5,15 , and $20 \%$. These simple inferences are largely robust to other cutoff choices. Additionally, our appendices also detail who qualifies as a "moderate" and "extremist" using this 10\% cutoff. 
an inappropriate analytical tool for examining variance in those scores. ${ }^{16}$ An individual legislator's party unity score is more properly viewed as a series of binomial trials coded one if a legislator is loyal to his or her party and zero otherwise. Fractional logit models help take proportions in which the numerator and denominator are known and expand them out into sets of zeros and ones. For example, we may observe 100 instances of a legislator opposing his or her party out of 1000 party line votes. This implies there are 100 ones and 900 zeroes in a binary coding of that legislator's opposition to his or her party during roll call votes. From this setup emerges a standard logistic regression predicting the probability of an outcome, given some attributes of the groups (in this case, legislators), but with no information about the trials (in this case, votes) themselves. Table 2 examines all roll call votes rather than just final passage votes. We differentiate final passage and procedural votes in subsequent analyses.

To provide an exogenous measure of legislative ideology, Table 2 reports a logistic regression predicting the probability a legislator votes loyally with his or her party as a function of the absolute value of his or her lagged DW-Nominate score. Lagged DW-Nominate scores are highly correlated with contemporaneous DW-Nominate scores and cannot be caused by contemporaneous party unity scores. Thus, lagged DW-Nominate scores satisfy many of the requirements of an effective instrument for overcoming endogeneity problems in a regression context. We then interact the absolute value of a legislator's lagged DW-Nominate score with his or her status as a majority party member. Our expectation is that majority party status means very different things to ideological moderates and ideological extremists. This in turn implies that the interaction of ideological extremity and majority party status should be statistically significant. ${ }^{17}$

${ }^{16}$ Some legislators have perfect party unity scores, which makes beta regression an inappropriate a modeling strategy, too.

${ }^{17}$ Our argument for leveraging lagged DW-Nominate scores is that we wish to use different sets of votes to estimate legislators' ideologies and party loyalties in order to avoid problems with sorting out which construct potentially causes the other. Using lagged measures of ideology ought to create a situation in which we estimate ideology from a set of votes unrelated to the votes for which we estimate party loyalty. However, DW-Nominate places strong restrictions on the amount 
To account for potentially competing explanations and the multilevel nature of our data, we also incorporate varying intercepts for each Congress and each legislator in our data. ${ }^{18}$ Thus, any variable that changes from one Congress to the next or from one legislator to the next is modeled in our fractional logit setup. For example, the ideological distance between the House parties has increased from one Congress to the next and the size of majorities change. These may in turn influence party loyalty, but the varying intercepts for each Congress account for this alternative explanation in our model. ${ }^{19}$ Some individual legislators may come from particularly safe Congressional districts, which also may influence their level of party loyalty, but again this alternative is accounted for by our varying legislator intercepts. We have also run models with a full set of covariates including seniority, freshmen, Southern, district presidential vote share, quality of challenger, and others. Our results are unaffected by the inclusion of those controls and we opt to present the simpler model here. The full model can be found in the Appendix.

The results from our multilevel fractional logit models in Table 2 indicate that as the absolute value of a legislator's lagged DW-Nominate score increases (indicating increased ideological extremity), the probability a legislator will vote loyally with his or her party increases, precisely as the of "movement" legislators can make in ideological space from one session to the next, allowing only linear changes in ideology over time. This restriction implies that DW-Nominate scores at time $t$ are closely related to scores at time $t-1$ by construction. This may imply that our use of lagged DW-Nominate scores is insufficient to overcome our endogeneity concerns. As such, in the supplemental appendix, we leverage new ideal point estimates from Asmussen and Jo (2016) that are both comparable over time, but unrestricted in the evolution of legislator ideology. Those results mirror the ones we present in the main body of the paper.

${ }^{18}$ Because most legislators appear in more than one Congress in our data set, we have plenty of degrees of freedom with which to include these different intercepts.

${ }^{19} \mathrm{We}$ also take an empirical approach to studying the influence of party size on the distribution of party defections in the supplemental appendices. As we would expect based on our theory, as small (and thus minority) parties grow in size (and become majority parties), extremists become less loyal while moderates become more loyal. 
Table 2: Multilevel Fractional Logit Models Predicting the Party Unity During Roll Call Votes in U.S. House Using DW-Nominate Scores (95th-112th Congress)

\begin{tabular}{l|cc}
\hline \hline Variable Name & Democrats & Republicans \\
\hline Absolute Value of DW-Nominate Score $t-1$ & $5.118^{*}$ & $3.529^{*}$ \\
& $(0.087)$ & $(0.075)$ \\
Majority Party Member & $0.571^{*}$ & $1.083^{*}$ \\
& $(0.218)$ & $(0.112)$ \\
Majority Party X Absolute Value of Ideologyt-1 & $-0.752^{*}$ & $-1.662^{*}$ \\
& $(0.047)$ & $(0.041)$ \\
Intercept & $0.339 *$ & $0.533^{*}$ \\
& $(0.171)$ & $(0.081)$ \\
\hline$\sigma_{\text {Congress }}$ & 0.195 & 0.050 \\
$\sigma_{\text {Legislator }}$ & 0.395 & 0.321 \\
$\mathrm{NIC}$ & 39264 & 30606 \\
$\mathrm{~N}$ & 3505 & 2791 \\
\hline
\end{tabular}

Note: Cell entries report coefficient values from fractional logistic regression models predicting the probability of party support by an individual House member on party lines votes as defined by Poole and Rosenthal (1991). Standard errors are reported in parentheses. Varying intercepts are included for each Congress and each legislator. Column (1) reports results for Democratic House members. Column (2) reports results for Republican House members. * indicates a p-value $<0.05$.

traditional spatial model would suggest. The results also indicate that this effect is conditional on a legislator's membership in the majority party. Because the models include an interaction term, the positive coefficient implies that when the absolute value of a legislator's lagged DW-Nominate score is zero (indicating a perfectly moderate lagged voting record), moving to the majority party increases a legislator's probability of voting loyally with his or her party. However, the interaction term is negative and larger than the coefficient on the majority party identifier. This implies that when the absolute value of a legislator's lagged DW-Nominate score is one (indicating perfectly extreme voting behavior), the marginal effect of majority party status is negative, and thus implies that ideological extremists become less loyal when they shift to the majority party. ${ }^{20}$

To illustrate these conditional effects more clearly, Figure 2 plots the predicted probability of a

${ }^{20}$ For Democrats, the marginal effect of majority party status for perfect moderates is 0.571 , while the marginal effect of majority party status for perfect extremists is $0.571-0.752=-0.181$. For Republicans, the marginal effect of majority party status for perfect moderates is 1.083, while the marginal effect of majority party status for perfect extremists is $1.083-1.662=-0.579$. 
loyal party vote for a perfectly moderate and perfectly extreme Democratic and Republican House member in both the minority and majority party. The left hand panel plots the probability of party loyalty for ideological moderates. For both Democrats and Republicans, there is a clear increase in the probability of party loyalty among ideological moderates as the party moves from minority party to majority party status. The right hand panel plots the predicted probability of party loyalty for ideological extremists, and paints a very different picture. Democratic extremists become slightly (though not significantly) less loyal when their party moves to the majority. Republican extremists, however, become significantly less loyal when their party moves to the majority. It is important to note that the y-axes of these plots are quite different because the absolute defection rates are quite different for moderates and extremists. Nevertheless, the model suggests that controlling for any Congress- or legislator-level variance, ideological moderates and ideological extremists respond to the switch to majority party status in very different ways. Moderates become much more loyal, while extremists become slightly less loyal. This squares quite well with the expectations emerging from our theory of grandstanding and strategic disloyalty. ${ }^{21}$

\section{Procedural Votes vs. Final Passage Votes}

Because our theory suggests that much of this strategic disloyalty is motivated by an effort to appeal to constituents, a further implication of our theory is that these effects should be most exaggerated on final passage votes. Final passage votes, as opposed to procedural votes, are much easier for citizens to understand and they generally pit the majority party's proposals directly against the status quo. Procedural votes on the other hand, are rather obscure and less publicly salient, even if they are particularly important for legislative outcomes.

Thus, we expect the patterns we observe in Table 2 to be more muted on less salient procedural votes, and more exaggerated on more public final passage votes. ${ }^{22}$ To test this hypothesis, Table

${ }^{21}$ We have also examined whether these initial results are conditioned by divided government in our appendices. We find limited evidence that divided government plays a role in the dynamics we observe.

${ }^{22}$ This strategy is optimal for both individual members and party leaders. Individual members 


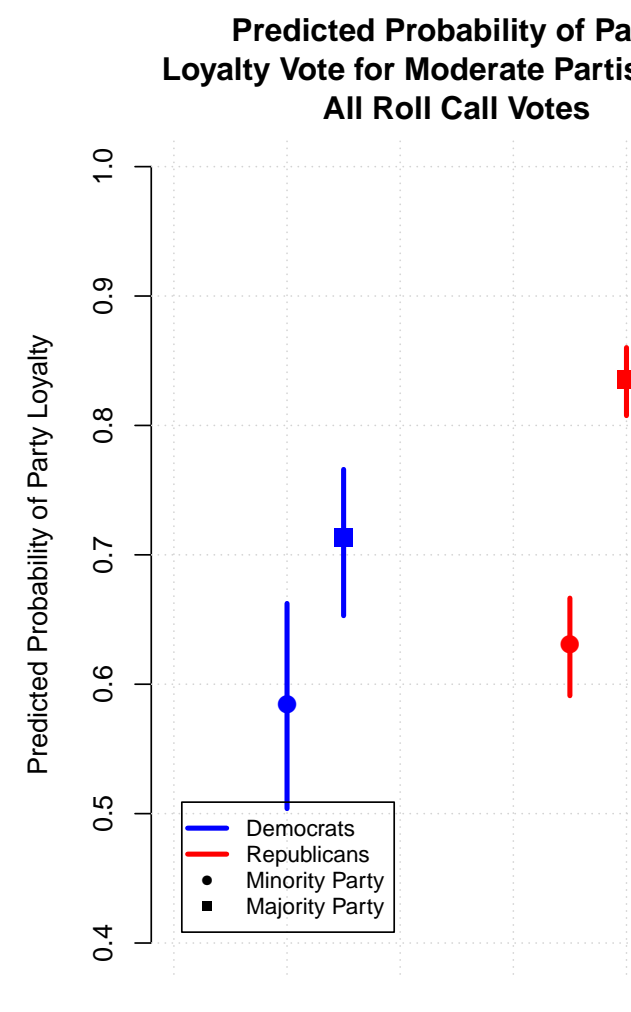

Party Affiliation

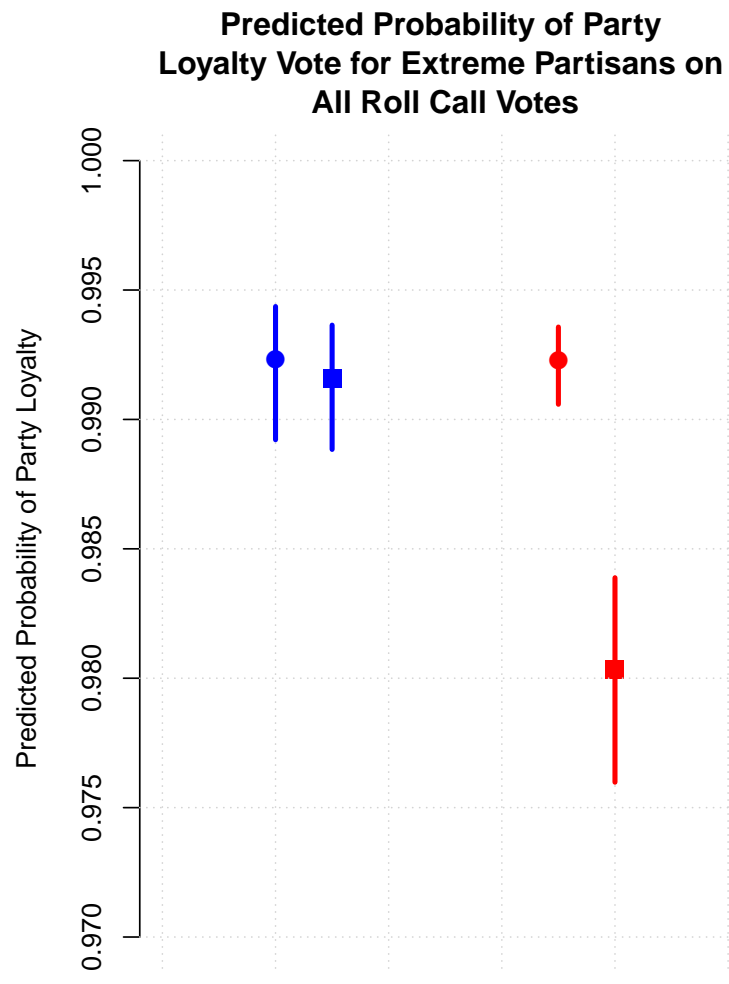

Party Affiliation

Figure 2: The Predicted Probability of Party Loyalty For Democrats and Republicans in the Majority and Minority as Lagged DW-Nominate Extremity Increases 
3 replicates the models in Table 2, but separates roll call votes into final passage votes and partisan procedural votes. Partisan procedural votes are roll call votes on procedures in the chamber intended to produce an advantage for the majority party. ${ }^{23}$ Final passage votes are votes to determine whether legislation passes in the chamber. Each legislator in the data set receives a party unity score on both partisan procedural votes and on final passage votes, which is correlated with, but distinct from their party unity score on all roll call votes. ${ }^{24}$

The effect of the absolute value of a legislator's lagged party unity score is consistently positive and statistically significant, while the interaction term of DW-Nominate scores with the majority party identifier is negative and significant in three of the four models. Thus, the expectations of the traditional spatial model that extremists will be more likely to defect from their party continue to see some support in our data. However, we remain primarily interested in the effects of majority party status on party loyalty, and whether transitioning from minority to majority party status has differential effects on ideological moderates and extremists. We expect that it does, and that these effects are more pronounced on final passage votes. To that end, Figure 3 plots the predicted probability of party loyalty for perfectly moderate and perfectly extreme Democratic and Republican legislators in the majority and minority party using the coefficients in Table 3 . The top panels plot these predicted probabilities on procedural votes while the bottom panels plot these relationships for final passage votes. The predicted probability of party loyalty on procedural votes is essentially unmoved by transitions from majority to minority party status for either moderate or extreme Democratic House members. However, exactly as we would expect, moderate Democratic can use final passage votes to score points with their constituents, while party leaders maintain loyalty on the votes that really matter (procedural votes). Party leaders accept some defection in order to help their rank-and-file win elections.

${ }^{23}$ Examples include votes on the motion to recommit (Roberts, 2005) and the motion to order the previous question (Finocchiaro and Rohde, 2008).

${ }^{24}$ Some votes are procedural votes not intended to produce a partisan advantage. For example, roll call votes approving the House journal may be party line votes without being intended to produce a partisan advantage (Patty, 2010). 


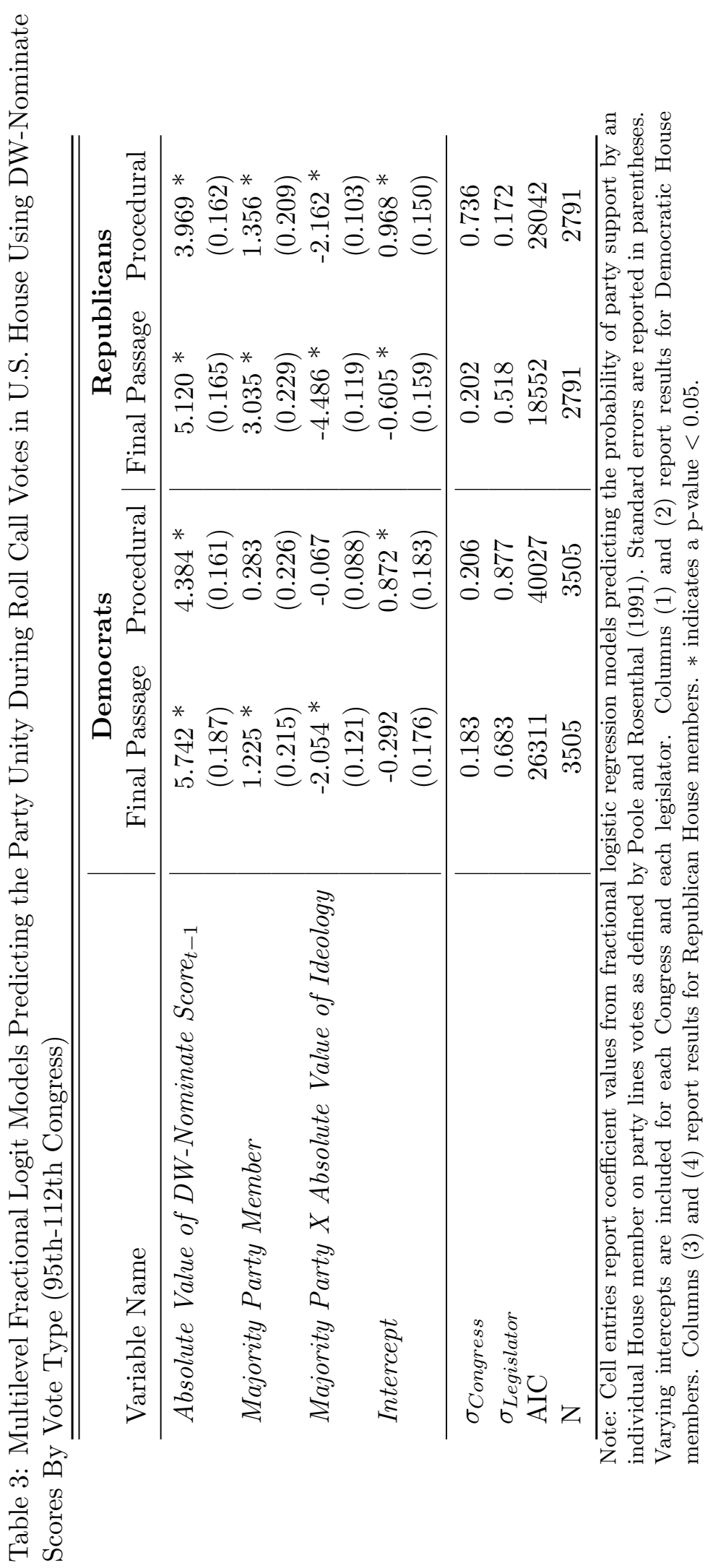


House members become much more loyal on final passage votes as they move from minority party to majority party status, while extreme Democratic House members become significantly less loyal on final passage votes when they switch from minority to majority party status. These effects are more consistent for Republican House members, who see moderates increase in loyalty and extremists decrease in loyalty when they join the majority across both vote types. However, these effects remain much stronger for final passage votes than for procedural votes even for Republican House members.

In sum, we consistently observe that controlling for any Congress-level or legislator-level alternative explanations, ideologically extreme legislators become less loyal when their party moves from the minority to majority party. Alternatively, ideologically moderate legislators become significantly more loyal when their party moves from the minority to majority. These conditional effects are strongest on the most public and salient votes, but are relatively weak on obscure votes meant to produce partisan procedural advantages. This would all seem to support our theory of strategic disloyalty and grandstanding. Legislators view final passage votes as chances to build their ideological brand, and are comfortable voting against their own party in order to improve their electoral odds. Because moderate and extreme legislators build different brands to court different kinds of voters, the effects of majority party status on their levels of party loyalty are quite different. This also suggests that the policy implications of these defections are limited. Legislators are more likely to defect from their party on final passage votes, when the legislative outcome has largely been assured. Very few House bills fail at final passage, while the most critical votes determining a bill's likelihood of moving on the process are procedural in nature. Thus, these strategic defections are intended to produce a signal to a legislator's constituents of his or her distance from the party, without actually compromising the party's policy goals in a meaningful way.

\section{Party Loyalty and Election Outcomes}

Our prior analysis demonstrates that majority party status effects the party loyalty of moderates and extremists differently, precisely as our theory would suggest. Beyond these expectations, our 

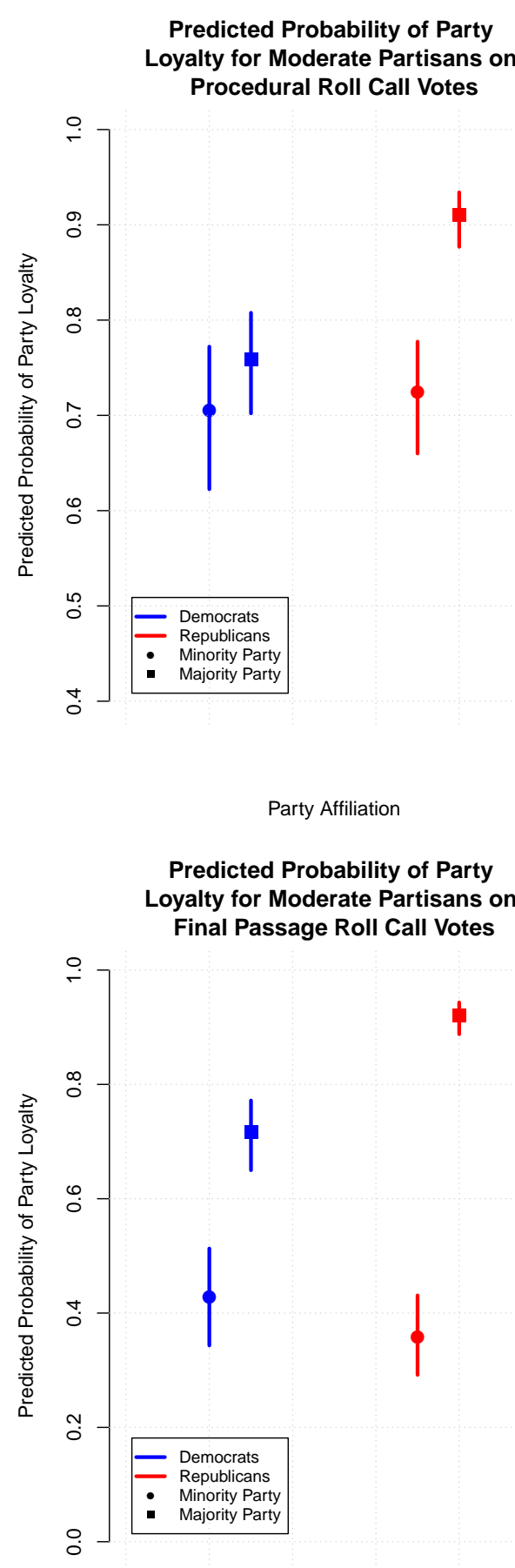

Party Affiliation

Predicted Probability of Party Loyalty for Moderate Partisans on Final Passage Roll Call Votes

Party Affiliation
Predicted Probability of Party Loyalty for Extreme Partisans on Procedural Roll Call Votes

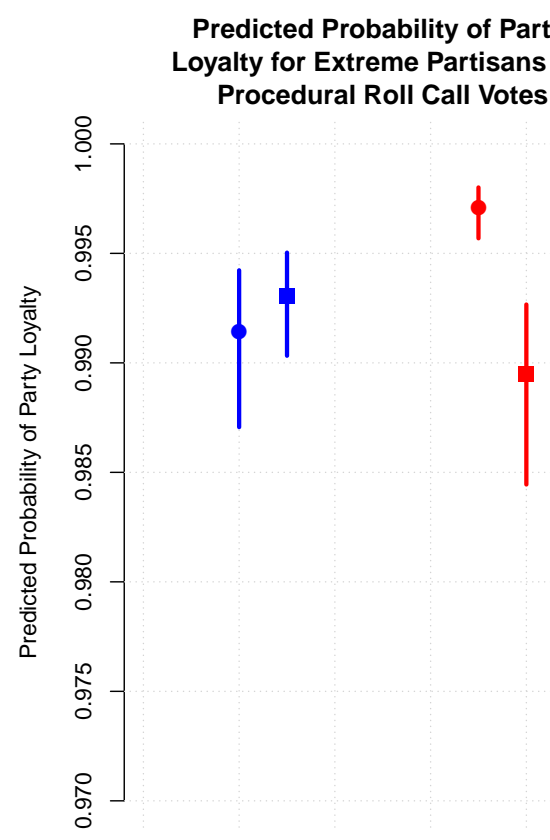

$$
11
$$

Party Affiliation

Predicted Probability of Party Loyalty for Extreme Partisans on Final Passage Roll Call Votes

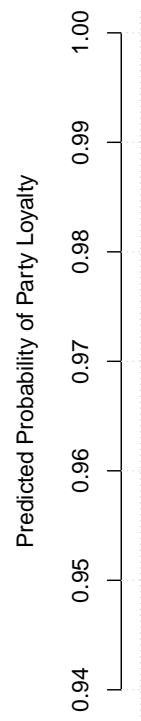

Party Affiliation

Figure 3: The Predicted Probability of Party Loyalty For Democrats and Republicans in the Majority and Minority as Lagged DW-Nominate Extremity Increases By Vote Type 
theory also suggests that these differences exist as a function of different electoral vote-maximizing strategies by moderates and extremists. Specifically, our theory would expect strategic defections to have an effect on electoral support, but disloyalty should benefit extremists and moderates differently, and also have differing effects on members of the minority and majority parties. In particular, extreme legislators in the minority ought to have a positive relationship between their own party loyalty and election outcomes, while extreme legislators in the majority ought to have a negative relationship between their party loyalty and their electoral fortunes. This would imply that not only are extreme legislators being more disloyal when in the majority, but that they have electorally-based reasons for doing so.

To test this implication, we extend the work of Carson et al. (2010). Carson et al. find that legislators who are loyal to their own party tend to suffer in subsequent elections, but they do not consider how this result might change for majority and minority party members, or that it might be conditional for members' ideology. Using replication materials provided by Carson et al., Table 4 predicts the share of the two-party vote for incumbents running for the 95th-108th U.S. House. We include (though we do not report) all of the controls included in Carson et al.'s models along with fixed effects for each legislator, but instead of assuming a uniform effect of party loyalty, we allow the effects of party loyalty on vote share to be conditional on ideological extremity as measured through DW-Nominate scores and majority party status. ${ }^{25}$ This conditional form requires the inclusion of a three-way interaction term and each of its constituent parts making the direct interpretation of the coefficients challenging. The important point to note from Table 4 is that there are a number of interactive effects between party unity, ideology, and majority party status. ${ }^{26}$ In particular, for

\footnotetext{
${ }^{25}$ More specifically, we predict a House member's vote share as a function of these covariates in the immediately preceding session of the House. Thus, vote shares in the 1994 elections are predicted as a function of covariates from the 1993-1994 House session. The appendix includes the full model results as well as other notes on our replication.

${ }^{26}$ The one difference between our model and Carson et al.'s is that we use the observed values of party unity rather than an instrumental variable approach. Because we are including interaction terms in our model, we would require effective instrumental variable values for each value of each
} 
a perfectly extreme House member with an absolute value of DW-Nominate of one, the marginal effect of party unity on two-party vote share is a positive and significant $18.981(-3.853+22.834)$ for a minority party member, and a negative and significant $-5.464(-3.853+22.834-7.749-16.696)$ for a majority party member. This means that minority party extremists gain electoral votes by being loyal while majority party extremists costs themselves votes by being loyal, exactly as our theory of strategic disloyalty would expect.

To facilitate clearer understanding of the model's results, Figure 4 plots the predicted twoparty vote share of a perfectly extreme House incumbent as her party unity increases using posterior simulation (King, Tomz and Wittenberg, 2000). The left hand panel of the figure reports results for a minority party extremists while the right hand panel reports results for a majority party extremist. All the other covariates in the model are held at their mean value. Moving from the minimum to the maximum of observed party loyalty, majority party extremists gain 19 percentage points of the two-party vote share by becoming more loyal, while majority party extremists lose 5 percentage points of the vote share by becoming more loyal. This suggests that the vote maximizing strategy for ideological extremists in the House is to be highly loyal in the minority party and disloyal in the majority party, precisely the pattern we observe on roll calls.

So far our analyses indicate that when ideological extremists become members of the majority party in the House, they systematically become less loyal, while moderates behave in the reverse direction becoming more loyal when joining the majority. We have also shown that this differential response to the change in party status by individual members is a vote-maximizing strategy. Further, in Supplemental Appendix E, we demonstrate that these differential responses are not just vote-maximizing strategies, but are actually the modes of representation preferred by citizens based on those citizens' ideologies. That is, we demonstrate that ideologically extreme citizens prefer policy representation from their representatives, while ideologically moderate citizens prefer a focus on distributional benefits from their representatives. These results mirror our assumptions that extreme and moderate members of Congress connect to their constituents in fundamentally different ways. Thus, this differential response to majority party status from moderates and extremists conditional term. For such a complex model, finding effective instruments is functionally impossible. 
Table 4: Time Series Cross-Sectional Regression Predicting an Incumbents Two-Party Vote Share (95th-108th Congress)

\begin{tabular}{|c|c|}
\hline Variable Name & Coefficients \\
\hline Two-Party Vote Share $_{t-1}$ & $\begin{array}{l}0.218 * \\
(0.014)\end{array}$ \\
\hline Majority Party Member & $\begin{array}{l}5.092 * \\
(2.299)\end{array}$ \\
\hline Absolute Value of Ideology & $\begin{array}{c}-26.314 * \\
(9.071)\end{array}$ \\
\hline Party Unity & $\begin{array}{l}-3.853 \\
(2.317)\end{array}$ \\
\hline Majority Party X Absolute Value of Ideology & $\begin{array}{c}19.632 \\
(10.115)\end{array}$ \\
\hline Majority Party X Party Unity & $\begin{array}{c}-7.749 * \\
(3.135)\end{array}$ \\
\hline Absolute Value of Ideology X Party Unity & $\begin{array}{c}22.834^{*} \\
(9.175)\end{array}$ \\
\hline Majority Party X Absolute Value of Ideology X Party Unity & $\begin{array}{l}-16.696 \\
(10.486)\end{array}$ \\
\hline Intercept & $\begin{array}{c}39.836 * \\
(3.629)\end{array}$ \\
\hline $\begin{array}{l}\text { Adjusted } R^{2} \\
\text { N }\end{array}$ & $\begin{array}{l}0.403 \\
3519\end{array}$ \\
\hline \multicolumn{2}{|c|}{$\begin{array}{l}\text { Note: Cell entries report coefficient values from time series OLS regression models predicting an } \\
\text { incumbents share of the two-party vote. Standard errors are reported in parentheses. Reported } \\
\text { models contains fixed effects for legislators. The model contains a number of additional contro } \\
\text { variables not reported in the Table. These include district partisanship as measured by district } \\
\text { presidential vote, a dummy indicator for a quality challenger, the natural log of challenger expen- } \\
\text { ditures minus the natural log of incumbent expenditures, a dummy indicating if the legislator was } \\
\text { a freshmen in the prior session, a dummy indicating if a legislator is a member of the president's } \\
\text { party, an indicator for midterm elections, as well as presidential approval over time, and change } \\
\text { in real disposable income over time. Data to construct the model as well as the set of controls } \\
\text { to include comes from Carson et al. (2010) and details on the measures can be found there. * * } \\
\text { indicates a p-value }<0.05 \text {. }\end{array}$} \\
\hline
\end{tabular}



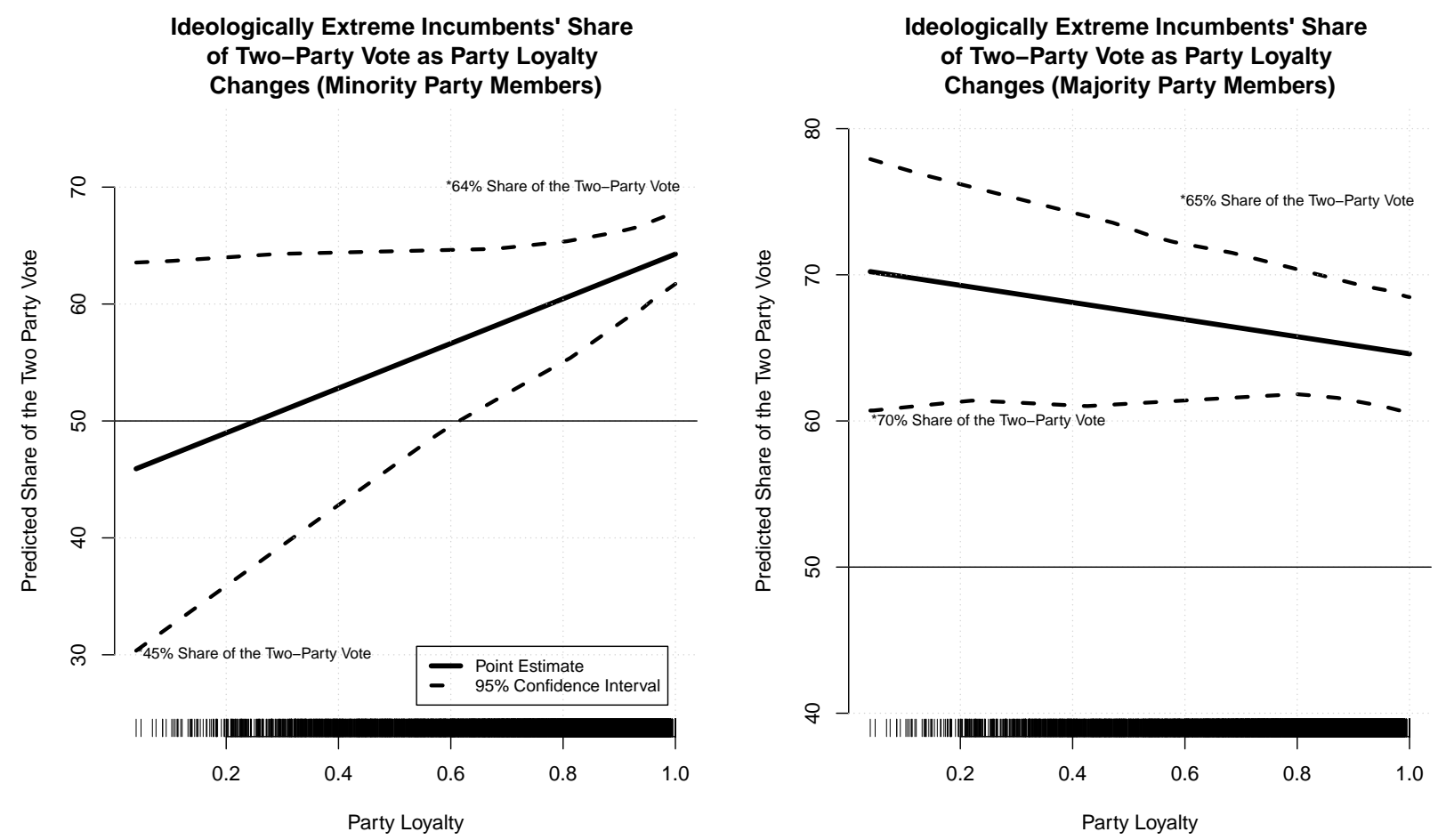

Figure 4: The Predicted Two-Party Vote Share of Majority and Minority Party Ideological Extremists as Their Party Loyalty Increases 
in Congress emerges because these representatives' voters expect very different things from them. Ideological extremists court ideologically extreme voters by concentrating on policy representation and ideological purity, precisely what those extreme voters desire from their representatives. Alternatively, ideologically moderate members of Congress connect to moderate voters by taking credit for the distributional benefits those moderate voters crave.

\section{Conclusion}

Our results add to recent literature suggesting that parties and members of Congress alter their behavior in ways that are inconsistent with the standard story of stable patterns of spatial voting (e.g. Lindstädt and Vander Wielen, 2014; Minozzi and Volden, 2013). Like other recent work (e.g. Minozzi and Volden, 2013), we find that members respond differently to party pressure depending upon their ideological stance. However, our findings also demonstrate that individual members change their behavior quite drastically when partisan control of the chamber shifts. Party majority status and ideology interact to produce patterns of party loyalty that standard models of parties in Congress do not predict. Existing research suggests that extremists should be more loyal and more susceptible to party influence than moderates, who are likely to be cross-pressured. No existing theory in the US Congress literature, though, expects extremists to defect from their party majority in a systematic manner. On average, we confirm that extremists are more loyal; but contrary to existing models, they are comparatively less loyal when members of the majority than when in the minority, particularly on more public, less substantive votes.

The defection patterns we uncover hold for members of both parties, but our results are stronger for Republicans. Moreover, because party control of the House changed in 1995 for the first time since 1955, the era of Congress driving our results effectively begins with Newt Gingrich's speakership in the House. Republicans in this era are more likely to pursue strategies of strategic loyalty and grandstanding. This finding provides further evidence for recent work suggesting that House Republicans adopted new adversarial strategies in this period to raise their profile and distinguish them from Democrats, which later had an effect on the functioning of the Senate (Theriault, 2013), 
and that parties in the House look increasingly similar to their parliamentary counterparts (Mann and Ornstein, 2012). Work on party loyalty in Westminster systems has long suggested that ideological extremists are more likely to defect than moderates (Gaines and Garrett, 1993; Benedetto and Hix, 2007; Kam, 2009) and that they do so for ideological reasons (Spirling and McLean, 2006; Proksch and Slapin, 2015).

Further, our work suggests that these grandstanding efforts have clear roots in electoral politics. Majority party extremists actually perform better in subsequent elections if they are less loyal, while majority party moderates and minority party extremists do best electorally when their party loyalty is quite high. Thus, there clear electoral incentives for extremists to become less loyal when in the majority. In our appendices, we demonstrate that the likely root of this electoral benefit comes from the fact that ideologically extreme citizens have a strong preference for policy representation, while ideological moderate citizens have a strong preference for distributive representation. Thus, the extreme citizens that form the base of an extreme Congressmen's re-election efforts demand policy purity from that representative.

Lastly, our findings suggest new avenues for future research on party behavior in the House. Our work focuses on the "supply side" of defection. That is, our work focuses on determining which set of members are likely to defect given an agenda. Many of the observations from our models might also be explained by a "demand side" story, in which moderates and extremists within a party debate over the agenda itself. In these circumstances, extremists may threaten defection as a tool to motivate more extreme party proposals, and then actually defect to demonstrate the credibility of that threat. We view these supply side and demand side stories as complementary, but future work may focus on determining the prevalence of each perspective as a motivator for individual-level changes in defection rates. Providing empirical support for the bargaining account may prove particularly difficult given the difficulties associated with locating bills in ideological space, but sorting out bargaining versus electoral motivations for disloyalty would represent an interesting addition to our own work.

In many ways, this distinction between disloyalty as a branding effort versus disloyalty as a bargaining tactic hinges on how comfortable party leaders are with defections. Party leadership 
is likely comfortable with some level of defection if it helps members win re-election, but just how much defection is tolerable? Similarly, party leaders are likely comfortable with capitulating to extremists' demands on some occasions, but not all. It is likely that leaders view different defections differently. Because defections on final passage votes are likely to be grandstanding, those defections would be unlikely to warrant sanctions from leaders, but defections by rank and file members on procedural votes may have more severe consequences. Future work could examine such differential reactions among party leaders to members' defections. 


\section{References}

Aldrich, John H. 1995. Why Parties? The Origin and Transformation of Political Parties in America. Chicago, IL: University of Chicago Press.

Aldrich, John H. and David W. Rohde. 2001. The Logic of Conditional Party Government: Revisiting the Electoral Connection. In Congress Reconsidered, ed. Lawrence C. Dodd and Bruce I. Oppenheimer. 7 ed. Washington, D.C.: CQ Press.

Angrist, Joshua D and Jörn-Steffen Pischke. 2008. Mostly Harmless Econometrics: An Empiricist's Companion. Princeton, N.J.: Princeton University Press.

Asmussen, Nicole and Jinhee Jo. 2016. "Anchors Away: A New Approach for Estimating Ideal Points Comparable across Time and Chambers." Political Analysis p. mpw003.

Balla, Steven J., Eric D. Lawrence, Forrest Maltzman and Lee Sigelman. 2002. "Partisanship, Blame Avoidance, and the Distribution of Legislative Pork." American Journal of Political Science $46(3): 515-525$.

Banks, Jeffrey S. 2000. "Buying Supermajorities in Finite Legislatures." American Political Science Review 94(3):677-681.

Benedetto, Giacomo and Simon Hix. 2007. "The Rejected, the Ejected, and the Dejected: Explaining Government Rebels in the 2001-2005 British House of Commons." Comparative Political Studies 40(7):755-781.

Binder, Sarah A. 1996. "The Partisan Basis of Procedural Choice: Allocating Parliamentary Rights in the House, 1789-1991." American Political Science Review 90(1):8-20.

Binder, Sarah A. 1997. Minority Rights, Majority Rule: Partisanship and the Development of Congress. Cambridge, MA: Cambridge University Press.

Bound, John, David A Jaeger and Regina M Baker. 1995. "Problems with Instrumental Variables Estimation when the Correlation Between the Instruments and the Endogenous Explanatory Variable is Weak." Journal of the American Statistical Association 90(430):443-450. 
Carroll, Royce, Jeffrey B. Lewis, James Lo, Keith T. Poole and Howard Rosenthal. 2013. "The Structure of Utility in Spatial Models of Voting." American Journal of Political Science $57(4): 1008-1028$.

Carrubba, Clifford J. and Craig Volden. 2000. "Coalitional Politics and Logrolling in Legislative Institutions." American Journal of Political Science 44(2):261-277.

Carson, Jamie L., Michael H. Crespin, Charles J. Finocchiaro and David W. Rohde. 2007. "Redistricting and party polarization in the US House of Representatives." American Politics Research $35(6): 878-904$.

Carson, J.L., G. Koger, M.J. Lebo and E. Young. 2010. "The electoral costs of party loyalty in Congress." American Journal of Political Science 54(3):598-616.

Clinton, Joshua, Simon Jackman and Douglas Rivers. 2004. "The Statistical Analysis of Roll Call Voting: A Unified Approach." American Political Science Review 98(2):355-370.

Cox, Gary W. and Mathew D. McCubbins. 1993. Legislative Leviathan: Party Government in the House. Berkeley, CA: University of California Press.

Cox, Gary W. and Mathew D. McCubbins. 2005. Setting the agenda: Responsible party government in the US House of Representatives. New York, NY: Cambridge Univ Press.

Crespin, M.H., D.W. Rohde and R.J. Vander Wielen. 2013. "Measuring variations in party unity voting: An assessment of agenda effects." Party Politics 19(3):432-457.

Crook, Sara Brandes and John R Hibbing. 1985. "Congressional reform and party discipline: The effects of changes in the seniority system on party loyalty in the US House of Representatives." British Journal of Political Science 15(02):207-226.

Dewan, Torun and Arthur Spirling. 2011. "Strategic Opposition and Government Cohesion in Westminster Democracies." American Political Science Review 105(2):337-358.

Downs, Anthony. 1957. An Economic Theory of Democracy. New York, NY: Harper and Row. 
Engstrom, Erik J. and Georg Vanberg. 2010. "Assessing the Allocation of Pork: Evidence from Congressional Earmarks." American Politics Research 38(6):959-985.

Fenno, Richard F. 1978. Home Style: House Members in Their Districts. Boston, MA: Little, Brown.

Finocchiaro, Charles J. and David W. Rohde. 2008. "War for the Floor: Partisan Theory and Agenda Control in the U.S. House of Representatives." Legislative Studies Quarterly 33(1):3561.

Gaines, Brian J. and Geoffrey Garrett. 1993. "The Calculus of Dissent: Party Discipline in the British Labour Government, 1974-1979." Political Behavior 15(2):113-135.

Grimmer, Justin. 2013a. "Appropriators not Position Takers: The Distorting Effects of Electoral Incentives on Congressional Representation." American Journal of Political Science 57(3):624642.

Grimmer, Justin. 2013b. Representational Style in Congress: What Legislators Say and Why It Matters. New York, NY: Cambridge Univ Press.

Groseclose, Tim and James N. Snyder. 1996. "Buying Supermajorities." American Political Science Review 90(2):303-315.

Harbridge, Laurel and Neil Malhotra. 2011. "Electoral Incentives and Partisan Conflict in Congress: Evidence from Survey Experiments." American Journal of Political Science 55(3):494-510.

Harbridge, Laurel, Neil Malhotra and Brian F. Harrison. 2014. "Public Preferences for Bipartisanship in the Policymaking Process." Legislative Studies Quarterly 39(3):327-355.

Harden, Jeffrey J. 2013. “Multidimensional Responsiveness: The Determinants of Legislators' Representational Priorities." Legislative Studies Quarterly 38(2):155-184.

Harden, Jeffrey J. 2015. Multidimensional Democracy: A Supply and Demand Theory of Representation in American Legislatures. Forthcoming: Cambridge University Press. 
Jacobson, Gary C. 1980. Money in Congressional Elections. New Haven, CT: Yale University Press.

Kam, Christopher J. 2009. Party Discipline and Parliamentary Politics. New York, NY: Cambridge University Press.

Keele, Luke, Suzanna Linn and Clayton McLaughlin Webb. 2016. "Treating time with all due seriousness." Political Analysis 24(1):31-41.

King, Gary, Michael Tomz and Jason Wittenberg. 2000. "Making the Most of Statistical Analyses: Improving Interpretation and Presentation." American Journal of Political Science 44(2):347361.

Kirkland, Justin H. 2014. "Ideological Heterogeneity and Legislative Polarization in the United States." Political Research Quarterly 67(3):533-546.

Krehbiel, Keith. 1993. "Where's the Party?" British Journal of Political Science 23(2):235-266.

Krehbiel, Keith. 1998. Pivotal Politics: A Theory of U.S. Lawmaking. Chicago, IL: University of Chicago Press.

Krehbiel, Keith. 2000. "Party Discipline and Measures of Partisanship." American Journal of Political Science 44(2):206-221.

Krehbiel, Keith, Adam Meirowitz and Thomas Romer. 2005. "Parties in Elections, Parties in Government, and Partisan Bias." Political Analysis 13(2):113-138.

Lawrence, Eric D., Forrest Maltzman and Steven S. Smith. 2006. "Who Wins? Party Effects in Legislative Voting." Legislative Studies Quarterly 31(6):33-69.

Lebo, M.J., A.J. McGlynn and G. Koger. 2007. "Strategic party government: Party influence in congress, 1789-2000." American Journal of Political Science 51(3):464-481.

Lee, Frances E. 2008. "Agreeing to Disagree: Agenda Content and Senate Partisanship, 1981-2004." Legislative Studies Quarterly 33(2):199-222. 
Lindstädt, René and Ryan J. Vander Wielen. 2011. "Timely Shirking: Time Dependent Monitoring and its Effects on Legislative Behavior in the U.S. Senate." Public Choice 148(1):119-148.

Lindstädt, René and Ryan J. Vander Wielen. 2014. "Dynamic Elite Partisanship: Party Loyalty and Agenda Setting in the US House." British Journal of Political Science 44(4):741-772.

Mann, Thomas E and Norman J Ornstein. 2012. It's even worse than it looks: How the American constitutional system collided with the new politics of extremism. Basic Books.

Minozzi, William and Craig Volden. 2013. "Who Heeds the Call of the Party in Congress?" The Journal of Politics 75(3):787-802.

Patty, John W. 2008. "Equilibrium Party Government." American Journal of Political Science $52(3): 636-655$.

Patty, John W. 2010. "Dilatory or Anticipatory? Voting on the Journal in the House of Representatives." Public Choice 143(1-2):121-133.

Patty, John W. and Elizabeth Maggie Penn. 2008. "The Legislative Calendar." Mathematical and Computer Modelling 48:1590-1601.

Poole, Keith T. 2005. Spatial Models of Parliamentary Voting. New York, NY: Cambridge University Press.

Poole, Keith T. and Howard Rosenthal. 1985. "A Spatial Model for Legislative Roll Call Analysis." American Journal of Political Science 29(2):357-384.

Poole, Keith T. and Howard Rosenthal. 2007. Ideology and Congress. Piscataway, New Jersey: Transaction Press.

Proksch, Sven-Oliver and Jonathan B. Slapin. 2012. "The Institutional Foundations of Legislative Speech." American Journal of Political Science 56(3):520-537.

Proksch, Sven-Oliver and Jonathan B. Slapin. 2015. The Politics of Parliamentary Debate: Parties, Rebels and Representation. Cambridge, UK: Cambridge University Press. 
Rice, Stuart A. 1925. "The behavior of legislative groups: a method of measurement." Political Science Quarterly 40(1):60-72.

Roberts, Jason M. 2005. "Minority Rights and Majority Power: Conditional Party Government and the Motion to Recommit in the House." Legislative Studies Quarterly 30(2):219-234.

Rohde, David W. 1991. Parties and Leaders in the Postreform House. Chicago, IL: University of Chicago Press.

Rohde, David W. 2013. "Reflections on the practice of theorizing: Conditional party government in the twenty-first century." The Journal of Politics 75(04):849-864.

Shepsle, Kenneth A. 1978. The Giant Jigsaw Puzzle. Chicago: University of Chicago Press.

Shepsle, Kenneth A. and Barry Weingast. 1987. "The Institutional Foundations of Committee Power." American Political Science Review 81(1):85-104.

Spirling, Arthur and Iain McLean. 2006. "The Rights and Wrongs of Roll Calls." Government and Opposition 41(4):581-588.

Theriault, Sean M. 2008. Party Polarization in Congress. New York, NY: Cambridge University Press.

Theriault, Sean M. 2013. The Gingrich Senators: The Roots of Partisan Warfare in Congress. Oxford, UK: Oxford University Press.

Weingast, Barry R. 1979. "A Rational Choice Perspective on Congressional Norms." American Journal of Political Science 23(2):245-262.

Weingast, Barry R. 1994. "Reflections on Distributive Politics and Universalism." Political Research Quarterly 47(2):319-327.

Wiseman, Alan E. 2004. "Tests of Vote-Buyer Theories of Coalition Formation in Legislatures." Political Research Quarterly 57(3):441-450. 


\title{
Supplemental Online Appendices
}

\author{
A - Two-Stage vs. Single-Stage Estimates of Vote Share in Carson et al. \\ B - Full Model Results With Controls \\ C - Incorporating Control Variables for a Model of Party Unity \\ D - Multilevel Model Details \\ E - Divided Government \\ F - Party Size \\ G - Citizen Ideology and Representational Priorities \\ $\mathrm{H}$ - Who is an Extremist? \\ I - An Alternative Measure of Legislator Ideology
}

\section{Appendix A - Two-Stage vs. Single-Stage Estimates of Vote Share}

In the manuscript, we provide a replication and extension of Carson et al.'s 2010 study of the electoral consequences of party loyalty. In that research, the authors find that increasing party loyalty results in losses in vote shares in subsequent elections. As an extension to this work, our analysis allows the effects of party loyalty to vary across individuals as their ideology changes and their majority-minority party status changes. Based on our theory, we expected party loyalty to help minority party extremists and hurt majority party extremists. Our results bare out this expectation quite well. However, there are some key differences in our analysis relative to Carson et al.'s such that our efforts are not an exact replication and extension. In this section, we detail some of these differences and provide some further interpretations of our model.

Perhaps the most important change to our model relative to its original specification, is that Carson et al. utilize an instrumental variable approach in their analysis. In particular, the authors are concerned about the degree to which party unity is endogenous or reciprocally related to electoral outcomes. Legislators and party leaders are capable of anticipating electoral outcomes and responding by changing the legislative agenda, while voters respond to legislators' own levels of 
party loyalty. To instrument party unity scores, Carson et al. utilize lagged party unity scores and ideological extremism. Our analysis has no instrumental variable approach for two reasons. First, standard econometric approaches to interactions with instrumental variables suggest that instruments must be created for each conditional value involving the instrument (Angrist and Pischke, 2008). That is, we would require an instrument for party unity, an instrument for party unity interacted with majority party status, an instrument for party unity interacted with ideological extremism, and an instrument for party unity interacted with majority party status and ideological extremism. It is unlikely that we could find effective instruments for so many different covariates, and incorporating weak instruments into regression analyses can cause a host of problems (Bound, Jaeger and Baker, 1995). The second reason we do not use the instrumental variables approach is that our analysis interacts party unity with ideological extremism, one of the key instrumental variables in Carson et al.'s analysis. Since one of the key instrumental variables in their analysis serves as a conditioning variable in our analysis, we cannot replicate their instrumental approach while also testing our expectations.

While we cannot both test our expectations and directly replicate Carson et al's work, we do want to demonstrate that using a standard single-stage regression rather than an instrumental variable approach does little harm to our inferences. In order to do this, we directly replicate the models reported in Table 2 of Carson et al's paper using both a single-stage and two-stage regression model. The results of this replication appear in Table 5. Columns (1) and (3) directly replicate the instrumental results of Carson et al. while columns (2) and (4) use a single-stage approach and observed values of party unity as a covariate. As is plain across the modeling approaches, the inferences regarding the relationship between party unity and two party vote share are unaffected by the use of two-stage instrumental variables approaches or single-stage approaches. Indeed the models in columns (1) and (2) are nearly identical with the only change of note being change of the coefficient on "in-party" status from positive and significant to negative and statistically insignificant. Otherwise, each coefficient is in the same direction, of roughly the same magnitude, and maintains its level of statistical significance. The models in columns (3) and (4) show even fewer differences. Each covariate in these models demonstrates exactly the same relationship with 
two-party vote share whether an instrumental approach is adopted or not. Given these results, we are confident that adopting an instrumental variable approach is unnecessary and that our use of raw party unity scores rather than instrumented party unity scores does little harm to the inferences we draw.

\section{Appendix B - Full Model Results}

Table 4 presents the key results of our hypothesis that party unity will differentially effect the electoral outcomes of House members. We find quite clearly that the effects of party loyalty are conditional both on a House members' ideological extremism and majority-minority party status. These results only present the key variables needed to test our expectations. Table 6 presents the full statistical results from our analysis. As we note in the main body, a number of control variables are included in the model. Our choice of controls was guided by Carson et al's analysis of two-party vote shares, as our analysis is a direct extension of theirs. As control variables, we include the district's presidential vote share, which is the presidential vote share of the presidential candidate sharing the party of the Congressional incumbent running in the election. We also include a dummy variable indicating whether the incumbent faced a quality challenger in the election using Jacobson's (1980) coding, the spending gap between the incumbent and his or her challenger, a dummy variable indicating whether the incumbent was a freshmen in the immediately preceding session, a dummy indicating whether the incumbent was the same party as the president ("inparty"), and a dummy indicating if the election was a midterm election. We also include measures of presidential approval and the change in real disposable income over time. Presidential approval is coded such that members of the president's party would receive high values when he is popular and out-party members would receive low values when the president is popular. Change in real disposable income is taken from the third quarter of the election year and is multiplied by -1 for members of the out-party. As noted, this is exactly the scheme employed by Carson et al. with our only addition being the multiplicative terms in the model.

As the results indicate, the associations between most of the control variables and two-party vote share are statistically significant. Only freshmen status fails to reach traditional thresholds of 


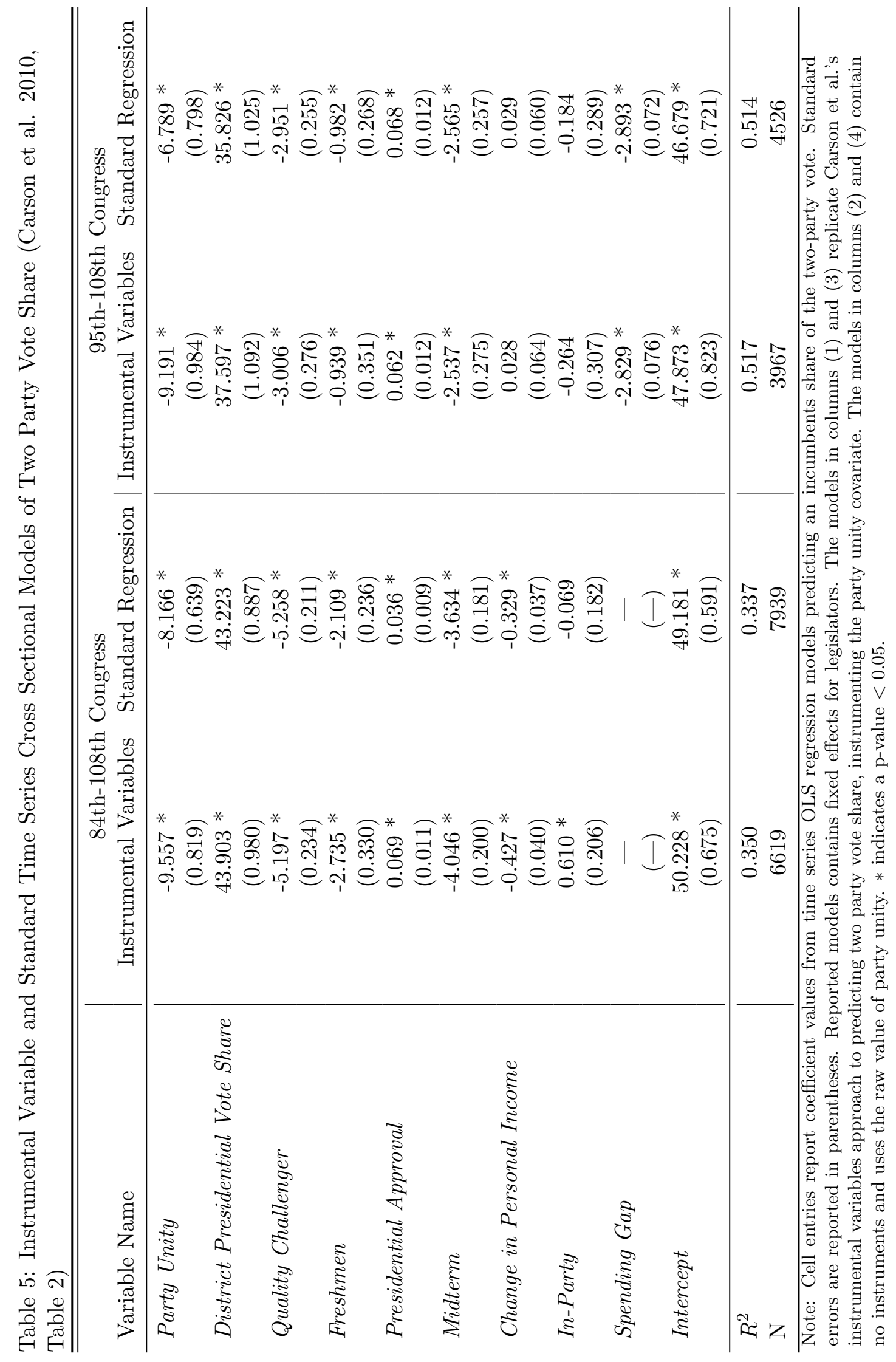


statistical significance. District presidential vote share, presidential approval, and in-party status all had positive effects on vote share, while the quality challenger dummy, the midterm dummy, change in personal income, and the spending gap between incumbents and challengers all had negative effects on two-party vote share. These results are in keeping with those we report in Table 5 .

As an effort to make the results in Table 4 more interpretable, Figure 4 plots the predicted vote share of ideological extremists in the majority and minority party. We focus on the extremists because their behavior seems most at odds with what traditional spatial models would expect, and thus, these results seem to be the most novel. However, our model also provides information about how party loyalty influences the vote share of ideological moderates. Using the results in Table 4, which are again a subset of the results in Table 6, Figure 5 plots the two-party vote share of perfectly moderate minority party and majority party incumbents as their party loyalty changes. As the figure indicates, increasing party loyalty results in decreases in two-party vote share for moderate legislators in both settings. The effect is stronger for majority party members, but both minority and majority party moderates cost themselves votes by being loyal to their parties. Thus, when moderate legislators become more loyal as a result of joining the majority party in the House, they are actually costing themselves electorally, though these costs are likely to be offset by their ability to accrue benefits for their district and to shape the legislative agenda now that they are pivotal members of the majority party.

\section{Appendix C - Incorporating Control Variables for a Model of Party Unity}

In the main body of our paper, we report results from models predicting individual legislators' probability of party disloyalty during roll call voting. Our primary interest in these models is identifying when individual legislators increase or decrease their level of party loyalty as a function of their own ideology and their majority party status. These are the two key constructs in our theory of strategic party disloyalty. As such, our models lack many traditional control variables associated with models of party loyalty, and account for these potential confounding variables through the use of Congress-level and legislator-level intercepts. It is important to emphasize that this approach 
Table 6: Time Series Cross-Sectional Regression Predicting an Incumbents Two-Party Vote Share (95th-108th Congress) - Full Results

\begin{tabular}{|c|c|}
\hline Variable Name & Coefficients \\
\hline Two-Party Vote Share $_{t-1}$ & $\begin{array}{l}0.218 * \\
(0.014)\end{array}$ \\
\hline Majority Party Member & $\begin{array}{l}5.092 * \\
(2.299)\end{array}$ \\
\hline Absolute Value of Ideology & $\begin{array}{c}-26.314 * \\
(9.071)\end{array}$ \\
\hline Party Unity & $\begin{array}{l}-3.853 \\
(2.317)\end{array}$ \\
\hline Majority Party X Absolute Value of Ideology & $\begin{array}{c}19.632 \\
(10.115)\end{array}$ \\
\hline Majority Party X Party Unity & $\begin{array}{c}-7.749 * \\
(3.135)\end{array}$ \\
\hline Absolute Value of Ideology X Party Unity & $\begin{array}{c}22.834^{*} \\
(9.175)\end{array}$ \\
\hline Majority Party X Absolute Value of Ideology X Party Unity & $\begin{array}{l}-16.696 \\
(10.486)\end{array}$ \\
\hline \multicolumn{2}{|l|}{ Controls } \\
\hline District Presidential Vote Share & $\begin{array}{c}24.335 * \\
(1.574)\end{array}$ \\
\hline Quality Challenger & $\begin{array}{c}-2.335 * \\
(0.279)\end{array}$ \\
\hline Spending Gap & $\begin{array}{l}-2.131 * \\
(0.080)\end{array}$ \\
\hline Freshmen & $\begin{array}{c}0.464 \\
(0.304)\end{array}$ \\
\hline Presidential Approval & $\begin{array}{l}0.109 * \\
(0.012)\end{array}$ \\
\hline Midterm & $\begin{array}{c}-3.522 * \\
(0.276)\end{array}$ \\
\hline Change in Personal Income & $\begin{array}{c}-0.322 * \\
(0.069)\end{array}$ \\
\hline In-party & $\begin{array}{l}1.991 * \\
(0.329)\end{array}$ \\
\hline Intercept & $\begin{array}{c}39.836 * \\
(3.629)\end{array}$ \\
\hline $\begin{array}{l}\text { Adjusted } R^{2} \\
\text { N }\end{array}$ & $\begin{array}{l}0.403 \\
3519\end{array}$ \\
\hline
\end{tabular}



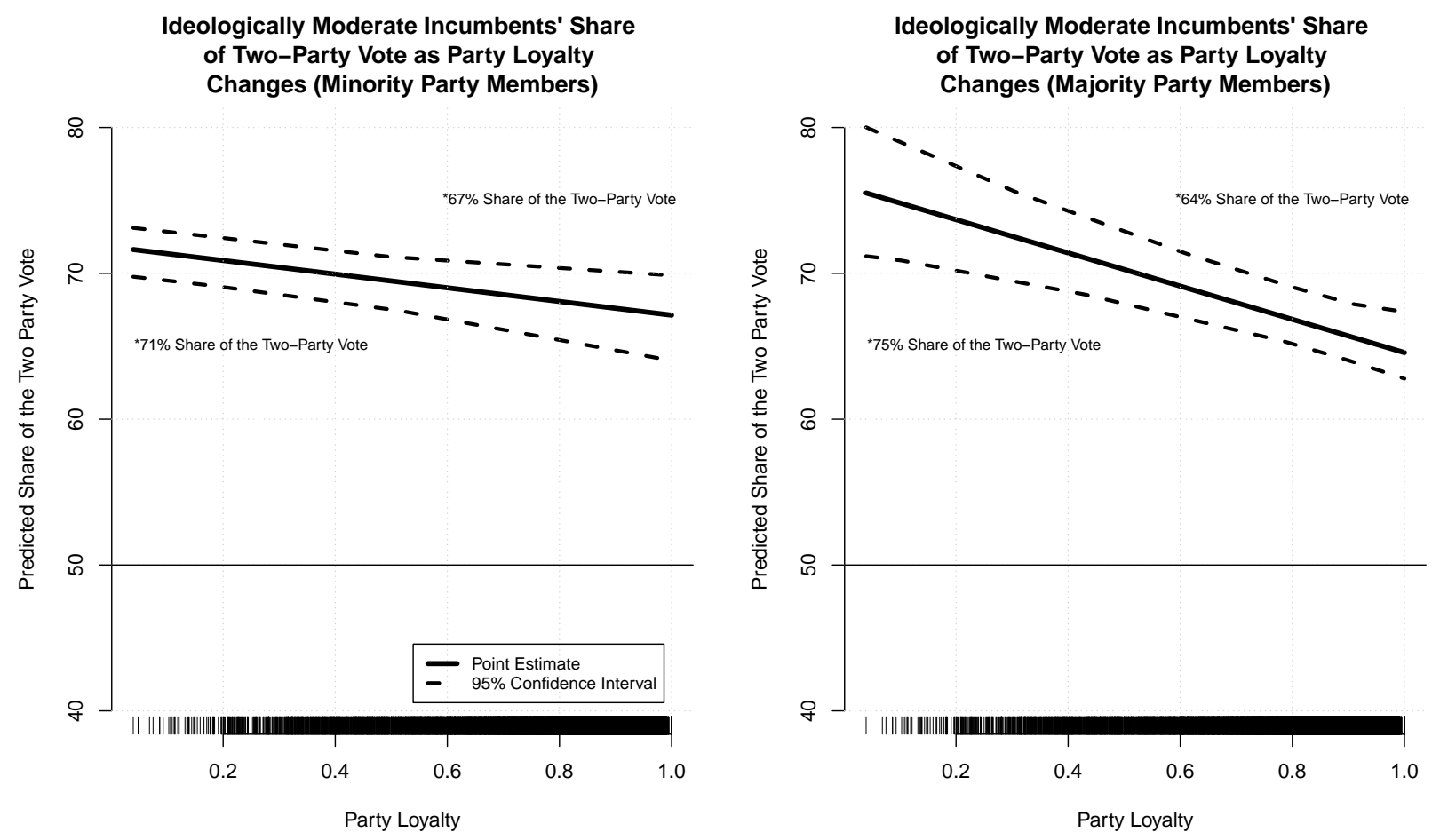

Figure 5: The Predicted Two-Party Vote Share of Majority and Minority Party Ideological Moderates as Their Party Loyalty Increases 
controls for any potential confounding variable that varies by legislator or Congress. In this way, our modeling approach is significantly more conservative than a model that incorporates some set of established control variables.

Nevertheless, the appearance of such a sparse model for testing our theory may seem odd to scholars more accustom to accounting for alternative explanations via additional covariates. Thus, Table 7 replicates our results from Table 2, but incorporates a variety of control variables prior research suggests may matter for predicting party loyalty. This model incorporates covariates for an individual legislator's seniority measured in years, freshmen status via a dummy variable coded one if the relevant legislator is a freshman and zero otherwise, a dummy variable identifying legislators from southern states, a dummy variable noting whether the legislators' district had recently been redistricted, a dummy variable noting whether a legislator's party was expected to gain seats at the midterm election, a lagged dummy variable noting if the legislator faced a quality challenger in the prior election, a measure of the lagged spending gap between a legislator and his or her challenger in the prior election, ${ }^{27}$ and the lagged vote share of the presidential candidate from the legislator's party in that legislator's district. These controls come from both Carson et al. (2010) and Lindstädt and Vander Wielen (2014). The models again include Congress-level intercepts and legislator-level intercepts to account for any unmeasured legislator-specific or Congress-specific variance unexplained by the covariates in the model.

Many of these control variables are themselves significant predictors of party unity. A legislator's level of seniority, the southern state identifier, the post-redistricting identifier, the presidential vote share measure, and the lagged challenger measures are all significant predictors of party unity in both models. Importantly, however, the incorporation of these controls does not change the conditional inferences from the main body of our paper at all. When a Democratic legislator is perfectly moderate, the effect of the majority party variable is a positive and significant 0.339 , meaning moderate legislators increase in their party loyalty when their party assumes the majority. For extreme Democrats, the marginal effect of joining the majority party becomes a negative and significant $-0.166(0.339-0.505)$. For Republicans, the results are quite similar. The marginal

\footnotetext{
${ }^{27}$ Campaign spending is logged and then differenced.
} 
Table 7: Multilevel Fractional Logit Models Predicting the Party Unity During Roll Call Votes in U.S. House Using DW-Nominate Scores and Control Variables (95th-112th Congress)

\begin{tabular}{|c|c|c|}
\hline Variable Name & Democrats & Republicans \\
\hline Absolute Value of DW-Nominate Score $_{t-1}$ & $\begin{array}{l}4.613 * \\
(0.125)\end{array}$ & $\begin{array}{l}3.432 * \\
(0.142)\end{array}$ \\
\hline Majority Party Member & $\begin{array}{l}0.339 * \\
(0.172)\end{array}$ & $\begin{array}{l}0.960 * \\
(0.124)\end{array}$ \\
\hline Majority Party X Absolute Value of Ideology $y_{t-1}$ & $\begin{array}{c}-0.505 * \\
(0.071)\end{array}$ & $\begin{array}{c}-1.322 * \\
(0.071)\end{array}$ \\
\hline Seniority & $\begin{array}{c}-0.009 * \\
(0.003)\end{array}$ & $\begin{array}{c}-0.012 * \\
(0.005)\end{array}$ \\
\hline Freshmen Status & $\begin{array}{c}0.026 \\
(0.014)\end{array}$ & $\begin{array}{l}-0.009 \\
(0.016)\end{array}$ \\
\hline Southern State Identifier & $\begin{array}{c}-0.512 * \\
(0.056)\end{array}$ & $\begin{array}{l}0.324 * \\
(0.058)\end{array}$ \\
\hline Post-Redistricting Identifier & $\begin{array}{c}-0.042 * \\
(0.019)\end{array}$ & $\begin{array}{l}0.062 * \\
(0.020)\end{array}$ \\
\hline District Presidential Vote Share $_{t-1}$ & $\begin{array}{c}-0.215 * \\
(0.086)\end{array}$ & $\begin{array}{l}0.335 * \\
(0.134)\end{array}$ \\
\hline Faced a Quality Challenger ${ }_{t-1}$ & $\begin{array}{l}0.056 * \\
(0.012)\end{array}$ & $\begin{array}{l}0.052 * \\
(0.012)\end{array}$ \\
\hline Spending Gap Between Incumbent and Challenger $r_{-1}$ & $\begin{array}{c}-0.015 * \\
(0.003)\end{array}$ & $\begin{array}{c}-0.006 * \\
(0.003)\end{array}$ \\
\hline Midterm Party Advantage & $\begin{array}{l}-0.095 \\
(0.057)\end{array}$ & $\begin{array}{l}-0.075 \\
(0.080)\end{array}$ \\
\hline Intercept & $\begin{array}{l}0.697 * \\
(0.159)\end{array}$ & $\begin{array}{l}0.262 * \\
(0.117)\end{array}$ \\
\hline$\sigma_{\text {Congress }}$ & 0.076 & 0.035 \\
\hline$\sigma_{\text {Legislator }}$ & 0.307 & 0.265 \\
\hline AIC & 19867.3 & 14449.6 \\
\hline $\mathrm{N}$ & 3505 & 2791 \\
\hline
\end{tabular}

Note: Cell entries report coefficient values from fractional logistic regression models predicting the probability of party support by an individual House member on party lines votes as defined by Poole and Rosenthal (1991). Standard errors are reported in parentheses. Varying intercepts are included for each Congress and each legislator. Column (1) reports results for Democratic House members. Column (2) reports results for Republican House members. * indicates a p-value $<0.05$. 
effect majority party identifier for moderate Republicans is a positive and significant 0.960, and is a negative and significant -0.362 for extreme Republicans. Thus, even after incorporating these control variables, moderate legislators in both parties become more loyal when their party assumes the majority, while extreme legislators in both parties become less loyal when their party assumes the minority.

To better illustrate these results, Figure 6 again plots the predicted probability of party disloyalty on roll call votes, but uses the coefficients from the models reported in Table 7 . These plots hold each of the control variables at either their mean or their mode, while allowing ideology

and majority party status to vary. Just as in Figure 2, the figure again indicates that moderate legislators become more loyal when their party becomes the majority and the reverse is true for extreme legislators. Again, our results indicate that this effect is stronger for Republicans. Thus, the incorporation of the control variables failed to influence our hypothesis tests in any way, and our conclusions appear to remain on solid empirical footing.

\section{Appendix D - Multilevel Model Details}

In the main body of our manuscript, we provide empirical evidence that the transition from minority to majority party status effects moderate and extremists in different ways. Our assertions are based a variety of multilevel fractional logit specifications, which we argue is the proper empirical approach to an analysis of party loyalty. In this section, we demonstrate the gains from such an approach and provide some additional material regarding our models' varying intercepts.

To begin, we wish to demonstrate that the multilevel fractional logit model is the proper empirical approach to such an analysis. In order to demonstrate this, we replicate our results from Table 2, but with two alternative specifications: a standard fractional logit model without varying intercepts, and a multilevel OLS model predicting party unity scores as percentages. We report these results in Table 8. In terms of the robustness of our earlier results, we see that across all six models, the coefficient on majority party status (indicating the effect of changing to the majority for ideological moderates) is positive and statistically significant. Additionally, across all six models, the interaction term is negative, significant, and larger than the majority party coefficient, 


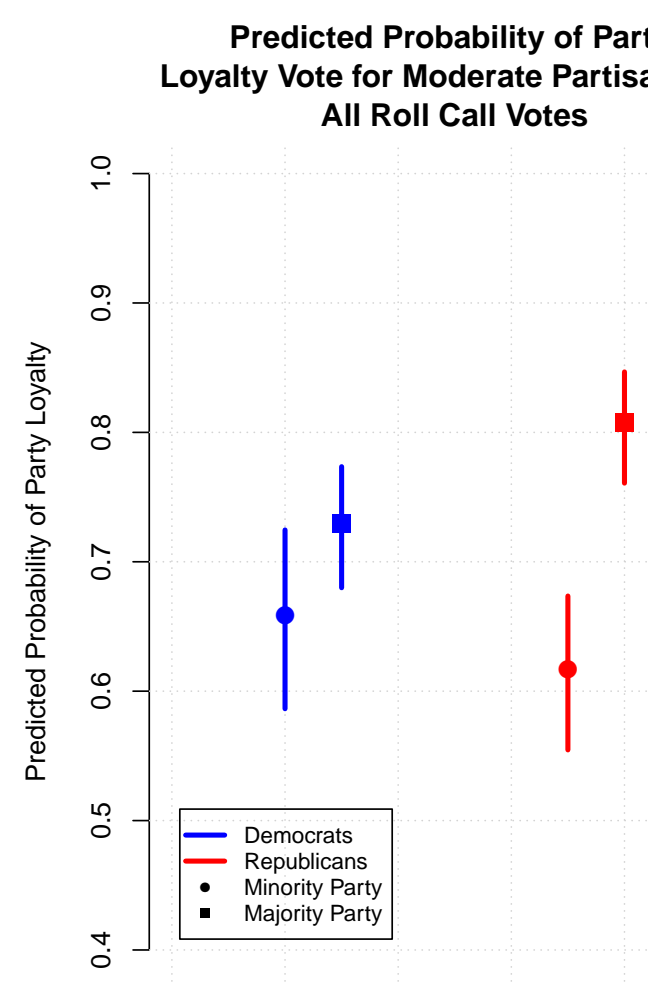

Party Affiliation
Predicted Probability of Party Loyalty Vote for Extreme Partisans on All Roll Call Votes

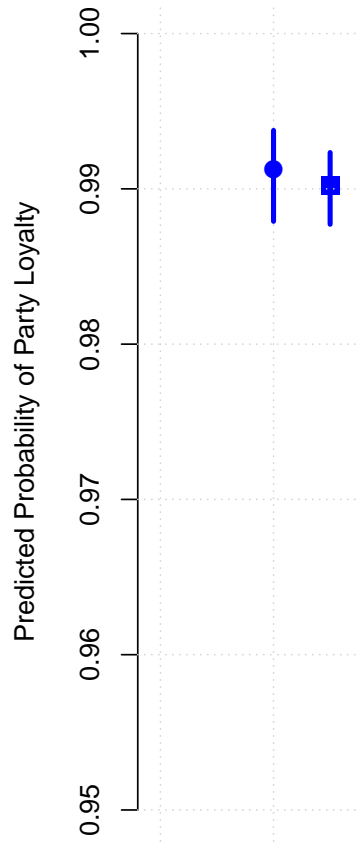

Party Affiliation

Figure 6: The Predicted Probability of Party Loyalty For Democrats and Republicans in the Majority and Minority as Lagged DW-Nominate Extremity Increases (incorporating controls) 
indicating that the effect of transitioning to majority party status on extremists' party loyalty is negative. Thus, our earlier model results suggesting that moderate and extremists react to the change to majority party status differently is supported across models without varying intercepts, and in more traditional OLS specifications.

It is worth noting that the models' predictive performance as measured by their respective AICs indicates that the OLS model has the highest level of predictive power. However, the OLS model also makes nonsensical predictions. For example, the intercept of the Democratic OLS model is 57.9 and the coefficient on lagged DW-Nominate scores is 76.6. This suggests that ideological extremists in the minority party have a party loyalty of 134.5 , an impossible score on a variable that ranges from 0 to 100. Thus, the multilevel fractional logit model pairs good predictive power with reasonable empirical predictions about the probability of party loyalty.

Our multilevel fractional logit models also provide varying intercepts across Congresses for both Democrats and Republicans, which for the sake of space, we do not report in the main body of the manuscript. Figure 7 plots these intercepts across each Congress. The intercepts represent the baseline level of party loyalty in our models, which thanks to our model specification is the level of party loyalty among perfectly moderate minority party members. Interestingly, these intercepts, though estimated from different models, track each other quite nicely. As the Republican intercept declines over time, the Democratic intercept increases with the Democratic intercept reaching its highest value at the point in which the Republican intercept is at its lowest point. The correlation between the intercepts over time is -0.609 .

\section{Appendix E - Divided Government}

Our theory focuses on how the party context in which legislators find themselves influences the likelihood that they will grandstand, or strategically defect, from their party's preferred position during a roll call vote. The particular context we are most interested in is a party's control of a chamber, as that control is largely determinative of both a) who is in control of the floor agenda of the chamber, and b) where potential defectors might emerge from during voting if the standard spatial model were true. However, other contextual forces may also influence a party's decisions 


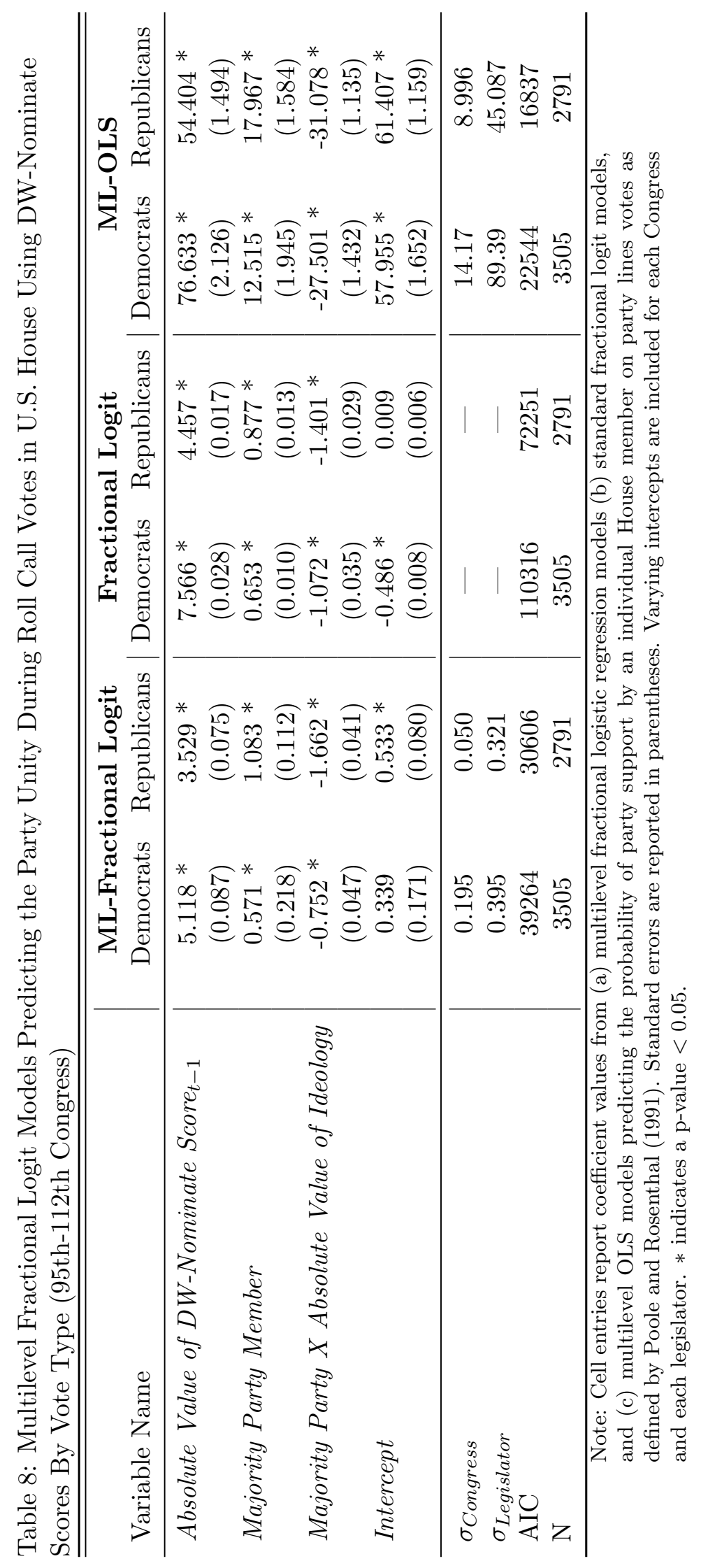




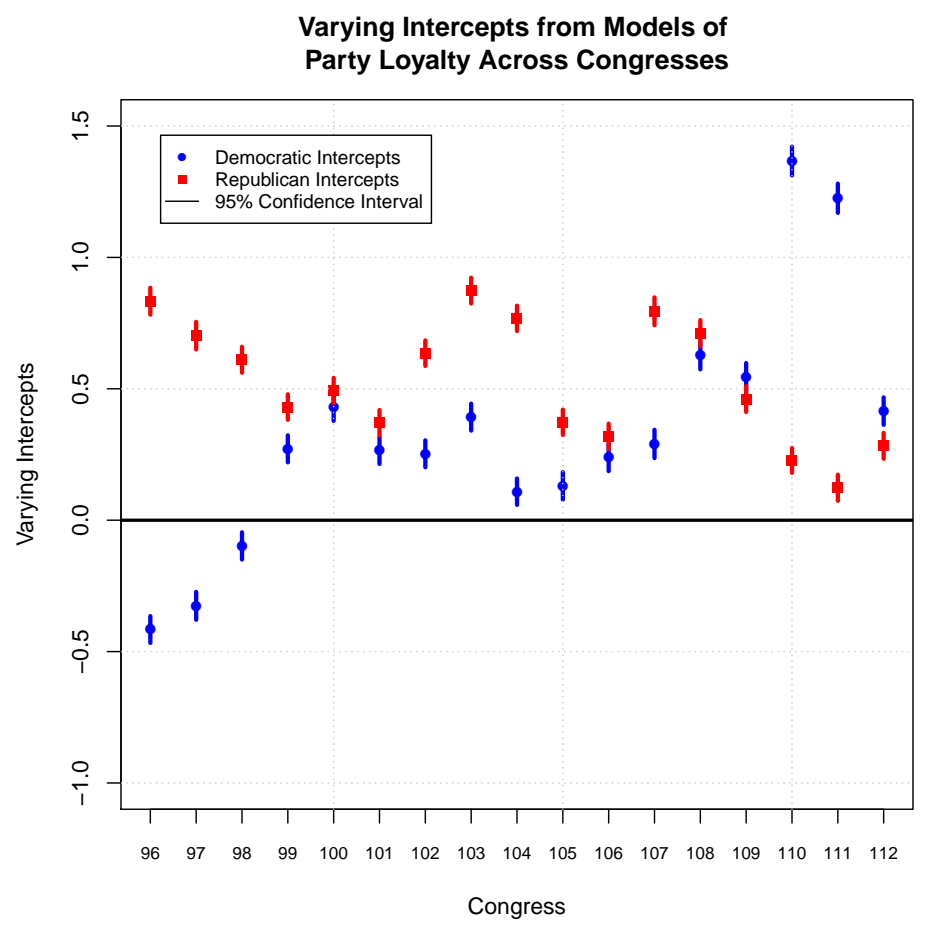

Figure 7: The Varying Intercepts of the Multilevel Fractional Logit Models in Table 8 by Congress.

about its legislative agenda, and thus, may influence the likelihood that some legislators defect from their party. In particular, divided government may play a role in structuring the types of bills that come to the House floor for consideration, and thus, from where we might observe defectors (Krehbiel, 1998).

However, simply incorporating a covariate for divided government into our existing modeling poses some challenges. In particular, divided government only varies over time (not by individual legislator), and changes in party status also only vary over time. With only 27 time points in our sample, incorporating both types of time-varying covariates into our model is likely to be overfitting the data, which can cause a host of problems in time series models (Keele, Linn and Webb, 2016). Instead, we adopt a split sample approach in which we re-estimate our models from Table 2, but divide our samples into divided government and unified government subsamples. The results of this subsampling exercise appear in Table 14. As we the Table indicates, in three of the four models, the effect of majority party status when ideological extremity is zero, represented by the coefficient 
on the majority party dummy, is positive and significant. Additionally, the interaction term on majority party status and ideological extremity is also negative and significant in the same three models. Both of these results are in keeping with our a priori expectations.

In order to be more precise in our interpretation of the interaction terms, Figure 8 plots the marginal effect of majority party status on the $\mathrm{y}$-axis, as ideological extremity increases on the $\mathrm{x}$ axis. For Republicans in divided and unified governments, and Democrats in divided governments, we observe precisely the relationships we expect, the move from minority party to majority party status is associated with positive increases in loyalty for moderates and negative increases in loyalty for extremists. However, we do see that under unified governments, the loyalty of Democrats is largely unrelated to their position in the majority. We should caution against over-interpreting these results. Our primary inferences are based on our ability to observe the same legislators in both majority and minority party settings, however, the Democrats did not often experience consecutive periods of unified government control. Thus, our ability to examine Democratic legislator under unified governments in both majority and minority settings is quite limited. Despite these inferential limitations, our results appear to be otherwise robust to concerns about divided government. We still see the comparative static we expected consistently for Republicans, and under most circumstances for Democrats (note that our sample sizes for divided government are much larger, because a divided federal government is much more common over our time period than a unified government).

\section{Appendix F - Party Size}

As we noted in the main body of our research, some scholars have noted that aggregate levels of party loyalty are likely to be tied to the sizes of political parties (Patty and Penn, 2008). Large parties are likely to be more difficult to keep cohesive, while small parties are more likely to act in unison. In order to deal with this potential confound (and indeed any other potential temporal confound), our main results leverage varying intercepts by session of Congress. This, of course, accounts for the possibility that baseline levels of loyalty might change as party sizes change, as extant theory on the topic would suggest. However, it is possible that party size conditions the 


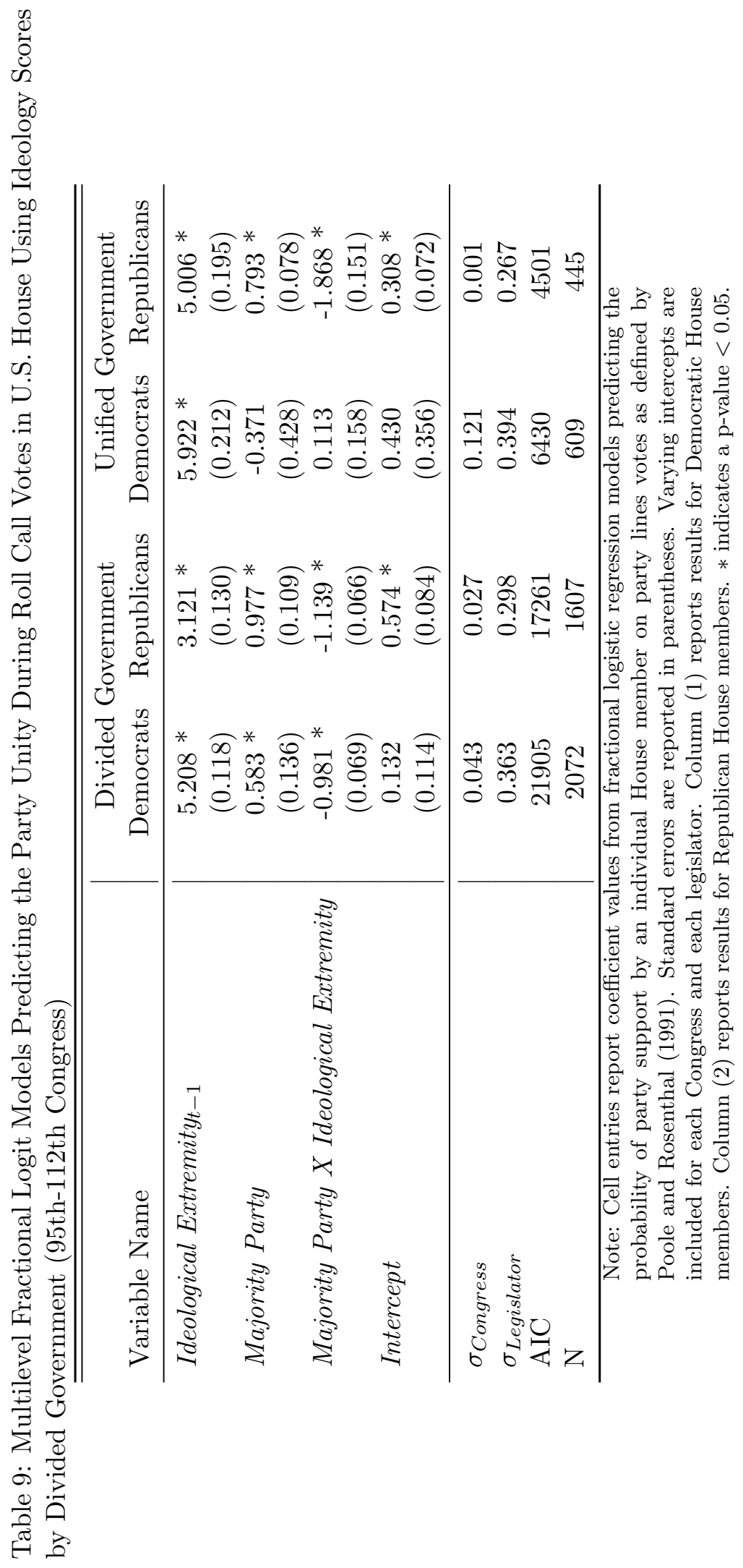



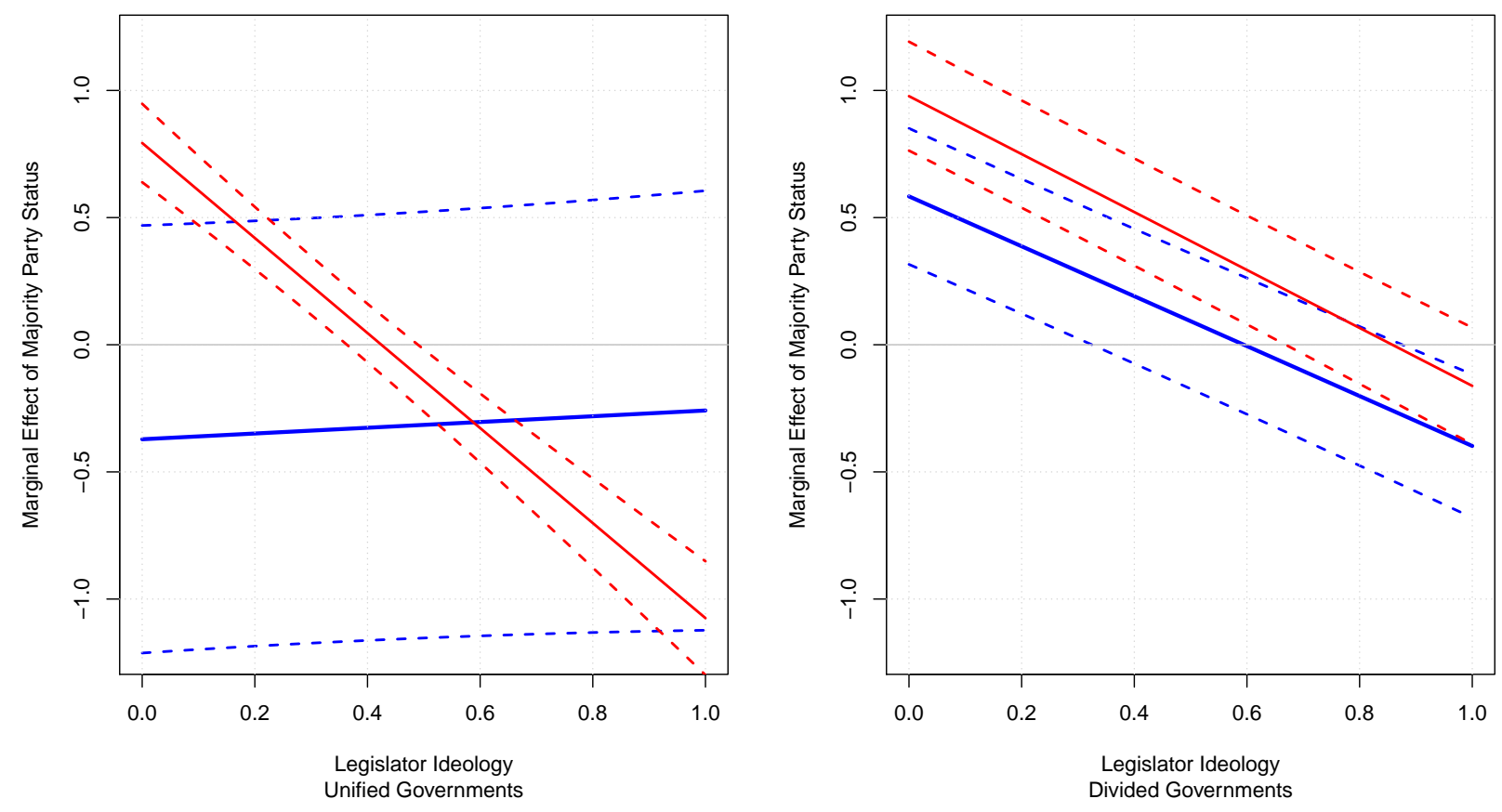

Figure 8: The Marginal Effect of Majority Party Status on Party Loyalty as Legislator Ideological Extremity Increases for Divided and Unified Governments 
effect of ideology on loyalty (rather than simply changing aggregate levels of loyalty). However, we again face a problem simply incorporating a covariate and interaction term for party size into our models. Again, the primary modifier we are interested in is majority party status, which is determined entirely by party size. Thus, there is not just a causal, but a deterministic relationship between our modifier of theoretical interest (majority party status), and party size.

While this is problematic from a modeling perspective, we still wish to examine how party size interacts with ideology to structure party loyalty. Our theory suggests that as parties move from minority to majority status, ideological extremists become less loyal and ideological moderates become more loyal. Another way to phrase these expectations is that as parties grow in size (presumably crossing from minority to majority status), extremists will become less loyal while moderates will become more loyal. Thus, we might re-estimate our models substituting measures of party size for party status. We perform this analysis in Table 10. Again, our expectation is that the party size coefficient will be positive, and the interaction term on party size and ideology will be negative. As the Table indicates, this is precisely what we observe empirically. For perfect ideological moderates where ideological extremity equals zero, the effect of growing party size on loyalty is a positive 0.142 for Democrats and 0.471 for Republicans. For perfect ideological extremists where ideological extremity equals 1 , the effect of growing party size on loyalty is a negative and significant -0.105 for Democrats and -0.218 for Republicans. Indeed, based on these results, any Democratic legislator whose ideological extremity is greater than 0.576 grows less loyal as party size grows (22.6\% of our Democratic sample) and any Republican legislator whose ideological extremity is greater than 0.683 grows less loyal as party size grows (21.2\% of our Republican sample).

\section{Appendix G - Citizen Ideology and Representational Priorities}

Our theory suggests that ideologically extreme representatives and ideologically moderate representatives connect to constituents in fundamentally different ways. We suggest that ideological extremists attempt to cultivate an image of ideological purity that causes them to occasionally oppose their own majority party's efforts to change the status quo, and ultimately helps them win re-election. Alternatively, ideologically moderate representatives are primarily interested in culti- 
Table 10: Multilevel Fractional Logit Models Predicting the Party Unity During Roll Call Votes in U.S. House Using DW-Nominate Scores and Party Size (95th-112th Congress)

\begin{tabular}{l|cc}
\hline \hline Variable Name & Democrats & Republicans \\
\hline Absolute Value of DW-Nominate Score $t-1$ & $4.901^{*}$ & $2.830^{*}$ \\
& $(0.096)$ & $(0.107)$ \\
Party Size & 0.142 & $0.471 *$ \\
& $(0.085)$ & $(0.069)$ \\
Party Size X Absolute Value of Ideologyt-1 & $-0.247^{*}$ & $-0.689^{*}$ \\
& $(0.028)$ & $(0.030)$ \\
Intercept & $0.426^{*}$ & $0.972^{*}$ \\
& $(0.086)$ & $(0.078)$ \\
\hline \multirow{2}{*}{$\sigma_{\text {Congress }}$} & 0.369 & 0.297 \\
$\sigma_{\text {Legislator }}$ & 0.075 & 0.048 \\
$\mathrm{AIC}$ & 29424 & 22189 \\
$\mathrm{~N}$ & 3505 & 2791
\end{tabular}

Note: Cell entries report coefficient values from fractional logistic regression models predicting the probability of party support by an individual House member on party lines votes as defined by Poole and Rosenthal (1991). Standard errors are reported in parentheses. Varying intercepts are included for each Congress and each legislator. Column (1) reports results for Democratic House members. Column (2) reports results for Republican House members. * indicates a p-value $<0.05$.

vating benefits for their district, and using credit-claiming strategies to enhance their re-election chances. The patterns we expect in both party loyalty rates and electoral results from that theory match up with our empirical analysis quite well. As an additional step in testing our theory, we also need to demonstrate that these preferences among members for ideological purity or district benefits have roots in what citizens expect from their representatives.

Prior research has suggested that representatives have a number of avenues for representing their constituents, and policy representation is only a part of the representative relationship (Harden, 2013, 2015). Representatives may also provide their constituents with constituency service, or ensure that their district receives distributional benefits from Congress. Due to the finite time legislators face in Congress, there are considerable tradeoffs in choosing how to best prioritize each mode of representation. Our theory suggests that ideologically extreme representatives are rewarded for ideological purity by their constituents, while ideologically moderate representatives are rewarded by their constituents for pork barrel success. This would suggest that as the ideological extremity of individual citizens increases, their preferences for their representatives to prioritize 
Introductory Text

Here is a list of some activities that occupy political representatives as part of their job. We want to know how important you think these activities are for three different types of representatives. Please rank these activities in order of importance by dragging them to the appropriate box.

\section{Direct Questioning}

1. Learning about constituents' opinions in order to better represent their views.

2. Helping constituents who have personal problems with government agencies.

3. Making sure the district gets its fair share of government money and projects.

Figure 9: 2010 CCES Question Regarding Respondents' Preferences for Representational Priorities.

policy representation ought to go up, and as the ideological extremity of citizens declines their preferences for their representatives to focus on allocation ought to go up.

In order to test these expectations, we use data from the 2010 Cooperative Congressional Election Study (CCES) that Harden (2015) uses to examining representational priorities in state legislatures. In addition to asking respondents about their preferences for the priorities of their state legislators, the 2010 CCES also asked respondents about their preferences for the priorities of their U.S. House Member. Respondents to the 2010 CCES were asked to rank their preferences for the activities of their representatives on three dimensions: 1) policy representation, 2) constituency service, and 3) allocation. A screen shot of the question wording respondents observed appears in Figure 9.

We develop a multinomial logit model to predict respondents' preferences for the representational priorities of their U.S. House member as a function of the ideological extremity of respondents, as well as several control variables. Ideology is measured on a standard seven-point scale, and thus, ideological extremity is measured as a four-point scale representing a respondent's distance from the midpoint of the ideology scale. As control variables, we also include a respondents income, a dummy variable indicating whether the respondent was employed, the respondent's level of education, the respondent's ideology itself (rather than ideological extremity), the respondent's party, the respondent's interest in politics, a dummy variable indicating the gender of the respondent, 
and two dummy variables indicating whether a respondent was white and whether a respondent was black. As this was a part of a specific module of the 2010 CCES, 1,000 respondents took part in the ranking exercise of which we have 790 usable responses. ${ }^{28}$ The results of our analysis appear in Table 11. The baseline dependent variable response is a preference for House members to focus on policy representation.

The interpretation of multinomial coefficients can be somewhat challenging. In our model, each covariate has two distinct effects, one on the probability of choosing for your representative to prioritize service over policy representation, and the other on the probability of choosing allocation over policy representation. Multinomial models force the probability of falling into one of the three categories to sum to one, such that these are not fully separate models, even though there are distinct effects for each category. As Table 11 reports, we find that there is a strong negative and significant effect of respondent ideological extremity on preferences for allocation over policy representation. That is, ideologically moderate constituents were more likely to choose for their representative to focus on allocation over policy representation, and more extreme constituents were more likely to choose policy representation over allocation.

In order to assist in the interpretation of the magnitude of these coefficients, Figure 10 plots the predicted probability of a respondent choosing policy representation as the priority of her representative and the probability of a respondent choosing allocation as the priority of her representative as ideological extremity increases, along with the $95 \%$ confidence intervals around those predictions. As the figures show, the predicted probability of ideologically moderate respondents preferring for their House members to focus on policy representation is 0.276 , while those same respondents have a probability of preferring that their House member focus on allocation of 0.450 . Alternatively, ideologically extreme respondents have a predicted probability of preferring their respondents focus on policy representation of 0.380 and a probability of preferring allocation oriented representation of 0.338 .

So in summary, ideologically moderate constituents have a strong preference for allocation over

${ }^{28}$ Our analysis also incorporates the survey weights provided by the 2010 CCES. 
Table 11: Multinomial Logistic Regression Predicting Respondents' Preferences for the Representational Priorities of U.S. House Members (2010 CCES)

\begin{tabular}{l|cc}
\hline \hline Variable Name & Constituency Service & Allocation \\
\hline Respondent's Ideological Extremity & -0.010 & $-0.222^{*}$ \\
Respondent's Income & $(0.089)$ & $(0.096)$ \\
Respondent's Employment Dummy & -0.035 & -0.049 \\
& $(0.029)$ & $(0.031)$ \\
Respondent's Educational Level & 0.547 & 0.183 \\
& $(0.334)$ & $(0.342)$ \\
Respondent's Ideology & 0.083 & $0.146 *$ \\
& $(0.070)$ & $(0.074)$ \\
Respondent's Party & -0.001 & 0.075 \\
Respondent's Interest in Politics & $(0.069)$ & $(0.075)$ \\
& -0.001 & -0.013 \\
Respondent is Female & $(0.058)$ & $(0.062)$ \\
& -0.189 & -0.054 \\
Respondent is White & $(0.191)$ & $(0.119)$ \\
& -0.323 & -0.085 \\
Respondent is Black & $(0.191)$ & $(0.202)$ \\
Intercept & -0.185 & $0.901 *$ \\
& $(0.285)$ & $(0.376)$ \\
\hline AIC & -0.596 & 0.182 \\
N & $(0.370)$ & $(0.464)$ \\
\end{tabular}

Note: Cell entries report coefficient values from a multinomial logistic regression predicting 2010 CCES responses to questions about the respondents' preferences for the representation priorities of their House members. Column (1) reports results for the effects of covariates on a preference for constituency service over policy representation. Column (2) reports results for the effects of covariates on a preference for allocation over policy representation. The baseline category of the dependent variable for the multinomial model is policy representation as a priority. * indicates a p-value $<0.05$. 

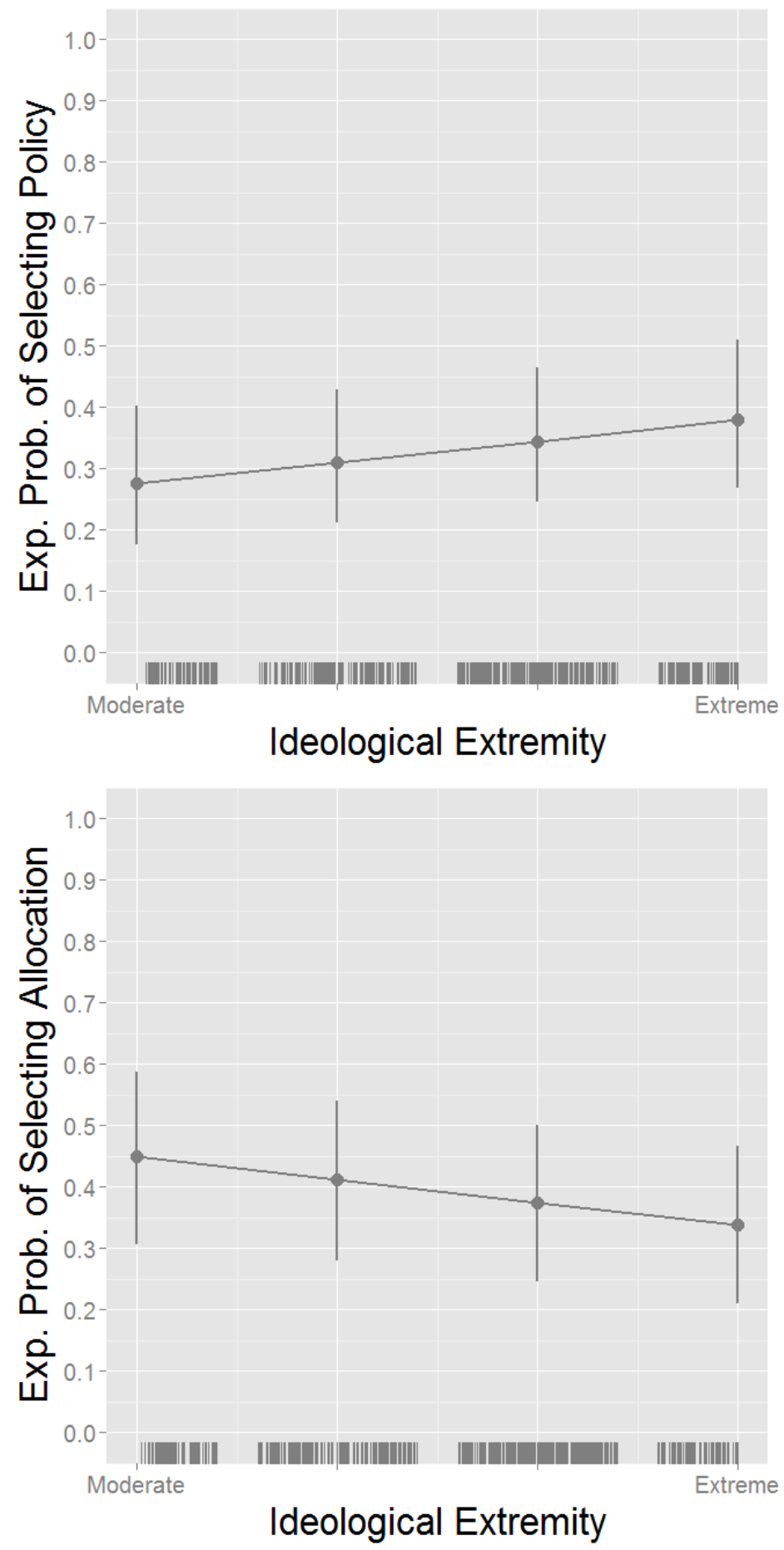

Figure 10: Predicted Probability of Choosing Allocation or Policy Representation Priority as Ideological Extremity Increases 
policy representation, while ideologically extreme respondents have a strong preference for (extreme) policy representation over allocation. This suggests that representatives hoping to develop electoral success before extreme constituents ought to focus on policy representation and ideologically extreme policy "purity", while representatives hoping to win re-election before ideologically moderate constituents would do well to focus on securing distributional benefits for their district. Thus, our assumption that ideologically extreme representatives connect to their constituents in different ways than ideologically moderate representatives, seems to be on firm footing. Representatives interested in winning re-election ought to behave in precisely the way our theory predicts.

\section{Appendix H - Who is An Extremist?}

In Table 1, we provide some simple descriptive evidence of the puzzle underlying our paper. We point out that there are clear patterns of different responses by extremists and moderates to majority party status. We hope that this exercise provides some "face validity" to our later inferences, which rely heavily on statistical modeling. Such modeling can create model dependence in results, and so, seeing some simple evidence of the patterns we expect seems valuable. To provide some more descriptive information about our results, Table 12 presents the 25 most extreme and moderate Democrat and Republican voting records in the House during the period we study. These names provide some examples of those to whom our conditional model most strongly applies. Our most extreme Democratic record belongs to noted liberal Dennis Kucinich (D-OH23) in the 112th session of the House, while our most extreme Republican records belongs to libertarian Ron Paul (R-TX14) also in the 112th session. Most of our most moderate records some from earlier sessions in our sample, reflecting the clear trend of ideological polarization in roll call voting that is so well established in congressional studies.

In addition to providing some additional descriptive evidence, we also want to demonstrate that the results of our simple hypothesis tests are not sensitive to our selected cutoff for moderates/extremists. In our initial efforts in Table 1, we chose the $10 \%$ most moderate and extreme ideal point scores for each party. In Table 13 we extend this analysis to report the differences between minority and majority party loyalty for extremists and moderates using 5, 10, 15, and 
Table 12: The 25 Most Moderate and Most Extreme Partisans (95th-112th Congress)

\begin{tabular}{|c|c|c|c|c|}
\hline Rank & Extreme Democrats & Moderate Democrats & Extreme Republicans & Moderate Republicans \\
\hline 1. & Kucinich - OH 112 & Huckaby - LA 95 & Paul - TX 112 & Smith - NJ 97 \\
\hline 2. & Washington - TX 101 & Taylor - MS 104 & Paul - TX 111 & Morella - MD 103 \\
\hline 3. & Washington - TX 102 & Breaux - LA 99 & Sensenbrenner - WI 112 & Anderson - IL 95 \\
\hline 4. & Washington - TX 103 & English - OK 97 & Paul - TX 110 & Rinaldo - NJ 98 \\
\hline 5. & Dymally - CA 102 & Tauzin - LA 97 & Sensenbrenner - WI 111 & Jeffords - VT 96 \\
\hline 6. & Kucinich - OH 111 & Huckaby - LA 96 & Sensenbrenner - WI 110 & Railsback - IL 97 \\
\hline 7. & Savage - IL 102 & Ray - GA 102 & Paul - TX 109 & Gilman - NY 97 \\
\hline 8. & McDermott - WA 112 & Condit - CA 101 & Sensenbrenner - WI 109 & Gilman - NY 98 \\
\hline 9. & Crockett - MI 101 & Hubbard - KY 101 & Paul - TX 108 & Pursell - MI 96 \\
\hline 10. & Stark - CA 112 & Fountain - NC 95 & Sensenbrenner - WI 108 & Jeffords - VT 95 \\
\hline 11. & Waters - CA 102 & Montgomery - MS 100 & Flake - AZ 112 & Boehlert - NY 99 \\
\hline 12. & Dymally - CA 101 & Huckaby - LA 97 & Flake - AZ 111 & Jeffords - VT 97 \\
\hline 13. & McDermott - WA 111 & Stanholm - TX 103 & Mulvaney - SC 112 & Horton - NY 102 \\
\hline 14. & Hayes - IL 101 & Cazayoux - LA 110 & Flake - AZ 110 & Boehlert - NY 98 \\
\hline 15. & Stark - CA 111 & Mathis - GA 96 & Amash - MI 112 & Horton - NY 101 \\
\hline 16. & Savage - IL 101 & Barnard - GA 102 & Walsh - IL 112 & Horton - NY 100 \\
\hline 17. & Waters - CA 103 & Tauzin - LA 96 & McClintock - CA 111 & Rinaldo - NJ 97 \\
\hline 18. & Stark - CA 110 & Nichols - AL 95 & McClintock - CA 112 & Williams - OH 96 \\
\hline 19. & McDermott - WA 110 & Hubbard - KY 102 & Flake - AZ 109 & Williams - OH 97 \\
\hline 20. & Lee - CA 105 & Hutto - FL 100 & Campbell - CA 109 & Williams - OH 98 \\
\hline 21. & Lee - CA 106 & Fountain - NC 96 & Campbell - CA 110 & Green - NY 102 \\
\hline 22. & Lee - CA 107 & English - OK 96 & Campbell - CA 111 & Johnson - CT 98 \\
\hline 23. & Lee - CA 108 & Mottl - OH 95 & Campbell - CA 112 & Morella - MD 104 \\
\hline 24. & Lee - CA 109 & Mottl - OH 96 & Labrador - ID 112 & Horton - NY 99 \\
\hline 25. & Lee - CA 110 & Mottl - OH 97 & Flake - AZ 108 & Gilman - NY 96 \\
\hline
\end{tabular}

Note: Cell entries report names, states, and sessions of the most extreme and most moderate voting records in our samples as measured by DW Nominate scores. 
Table 13: Difference of Means in Party Loyalty Rates on Final Passage Votes For N\% Most Moderate and N\% Most Extreme Partisans (95th-112th Congress)

\begin{tabular}{l|cccc}
\hline \hline & $\begin{array}{c}\text { Cutoff=10\% } \\
\text { Difference in Loyalty }\end{array}$ & $\begin{array}{c}\text { Cutoff=5\% } \\
\text { Difference in Loyalty }\end{array}$ & $\begin{array}{c}\text { Cutoff=15\% } \\
\text { Difference in Loyalty }\end{array}$ & $\begin{array}{c}\text { Cutoff=20\% } \\
\text { Difference in Loyalty }\end{array}$ \\
\hline Democratic Extremists & $-5.822^{*}$ & $-8.433^{*}$ & $-4.874^{*}$ & $-4.095^{*}$ \\
Democratic Moderates & $7.791^{*}$ & $9.596^{*}$ & $7.028^{*}$ & $5.709^{*}$ \\
Republican Extremists & $-3.016^{*}$ & $-6.388^{*}$ & -1.096 & 0.728 \\
Republican Moderates & $48.498^{*}$ & $49.452^{*}$ & $46.033^{*}$ & $42.486^{*}$ \\
\hline
\end{tabular}

Note: $*$ indicates a p-value $<0.05$.

$20 \%$ as cutoffs for moderation and extremity. Of the 16 difference of means we estimate, 14 demonstrate precisely the relationship we expect, that is less loyalty for extremists and more loyalty for moderates. Thus, these initial descriptive inferences appear to be robust to our choice of cutoff. Again, this is meant to be largely descriptive evidence, with more complete modeling appearing in Tables 2 and 3, but we see that the pattern of interest to us is sustained across choices of cutoffs.

\section{Appendix I - An Alternative Measure of Legislator Ideology}

Throughout our analyses, we have leveraged lagged DW Nominate scores as measures of legislator ideology. This is largely an effort to overcome problems of endogeneity, or more simply, to avoid using one aggregation of voting to predict another aggregation of voting as would happen if we used contemporaneous ideal point estimates and party loyalty scores. Thus, we suggest that by lagging DW Nominate scores, we use a prior set of votes to estimate ideal points and a current set of votes to estimate loyalty. In time series analyses, we generally do not think of the present as a cause to the past, so by using lagged DW Nominate scores, we hoped to overcome the problem of both using votes to predict votes, and the potential endogeneity issues of determining whether ideology causes loyalty or loyalty causes ideology.

Unfortunately, DW Nominate scores are correlated with themselves over time. This over time correlation is by construction, as the DW Nominate algorithm limits the types of "movement" legislators can make in ideological space, restricting their over time evolution in ideal points to linear movements from prior positions. This opens our analyses up to back door paths of endogeneity wherein because contemporaneous DW Nominate and party loyalty scores are endogenously related 
to each other, and contemporaneous and lagged DW Nominate scores are related to each by construction, the use of lagged DW Nominate scores does not free us entirely from our endogeneity concerns. To avoid these problems, we require some measure of legislator ideologies over time in which there is no forced association between ideal points for individual legislators. Fortunately, recent advances in ideal point estimation provide just such a measure.

To fully circumvent these problems, we leverage "Anchors Away" ideal point estimates developed by Asmussen and Jo (2016). Asmussen and Jo develop comparable over time estimates of legislator ideologies by bridging between sessions of Congress using bills introduced in multiple sessions of the House, rather than by limiting legislators' ideological movements. Thus, any over time correlation in legislators' ideal points is because of stable ideology rather than by construction of the ideal point measure. Because the past plays no role in the Anchors Away measurement of ideology, lagged versions of these ideal points ought to satisfy all of the criteria of a quality instrument. For legislators whose ideology does not evolve much over time, lagged Anchors Away scores should serve as a good proxy for current ideological extremity, and by the measures construction, the votes on which we measure party ideology cannot influence lagged ideal points.

In order to ensure that our use of lagged DW Nominate scores is not the cause of the results we observe, Table 14 re-estimates our models in Table 3, but substitutes the Anchors Away ideal points for DW Nominate scores. Because the Anchors Away estimates are constructed only after the 101st session of Congress, our sample in Table 14 is slight smaller than our primary results. To review our expectations, we expect that the effect of majority party status will be positive, the interaction between lagged absolute ideal point estimates and majority status will be negative, and these effects will be stronger on final passage votes than procedural votes. From the Table, we see that the first two of these expectations are met across all four of our models. The coefficient on majority party status is consistently positive and significant (and larger for passage votes than procedural votes), and the coefficient on the interaction term is consistently negative and significant.

As with any interactive model, examining the coefficients alone is insufficient for discussing all the inferences to be drawn from the model. As such, Figure 11 plots the probability of defections for perfectly moderate and extreme legislators (defined by being at the minimum and maximum 


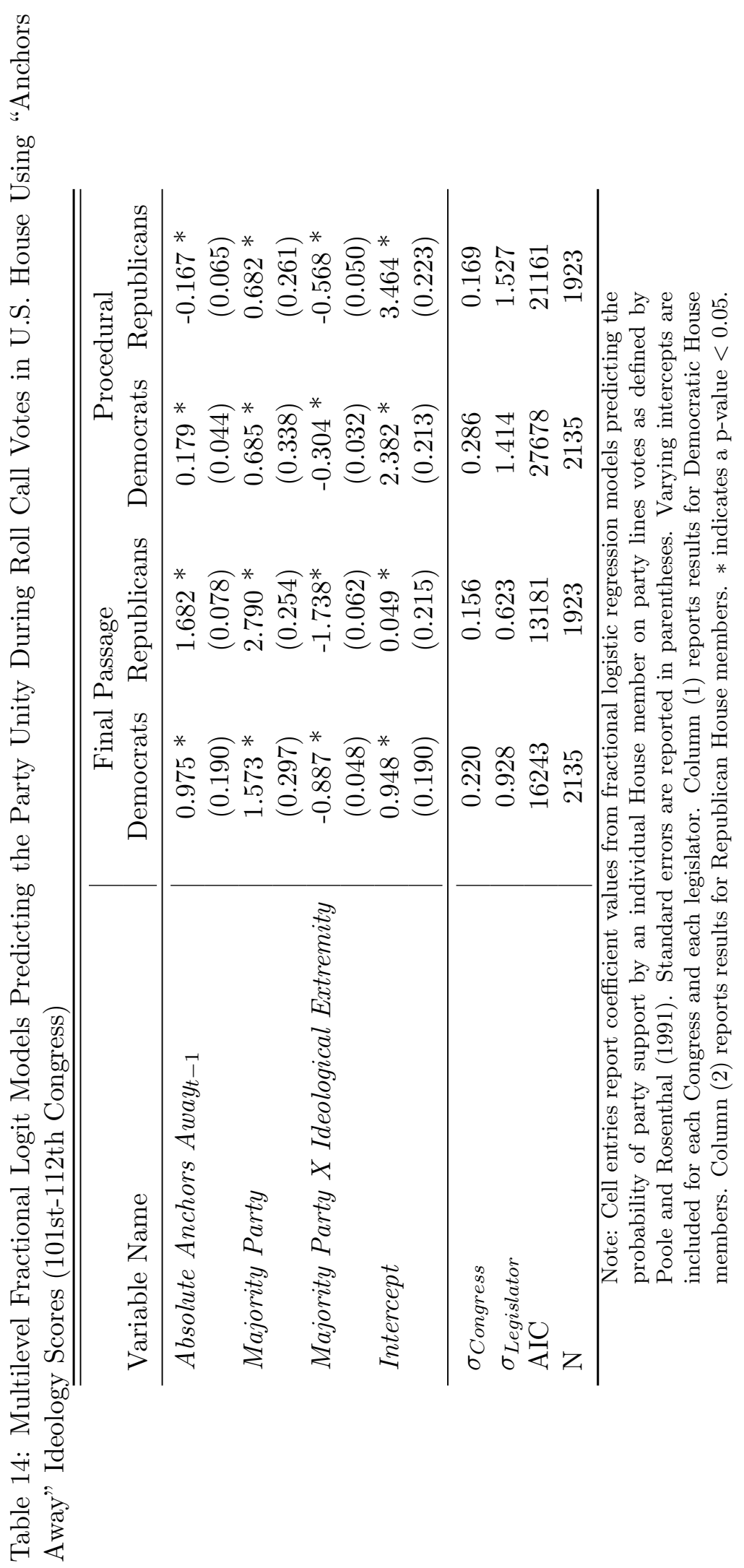


absolute value of the Anchors Away measure), for both Democrats and Republicans in the minority and majority parties. As the figure makes plain, for both parties, perfect ideological moderates become dramatically more loyal when their party moves from minority to majority status, while extremists become markedly less loyal during this same transition. This effect is also more pronounced on final passage votes, just as it was when we leveraged DW Nominate scores for our analyses. Thus, it would seem that our inferences and conclusions are robust to this alternative choice of ideal point estimates. 

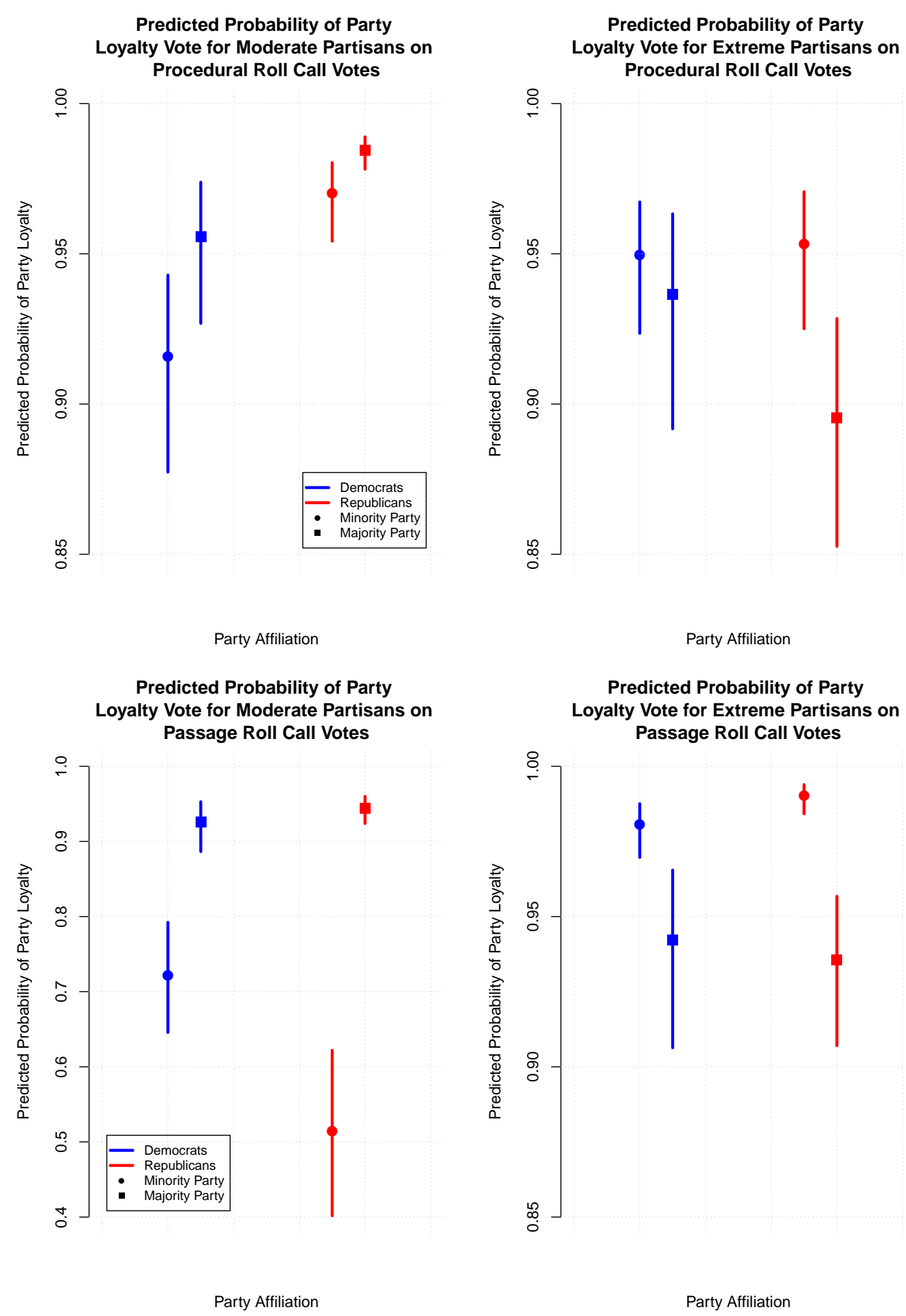

Figure 11: The Predicted Probability of Party Loyalty For Democrats and Republicans in the Majority and Minority as Lagged "Anchors Away" Extremity Increases By Vote Type 